\title{
مستوى الطموح لدى طلاب المرحلة الثانوية
}

\author{
إعراد
}

الباحثة/ عائشة فرج محمد المنشوف

إشرافـ

$$
\begin{aligned}
& \text { أ.د/حسين محمد سعد الدين الحسيني } \\
& \text { أستاذ علم النفس } \\
& \text { كليتالآداب_جامعتالمنصورة }
\end{aligned}
$$

$$
\begin{aligned}
& \text { المجلت العلميت لكليتترياض الأطفالـ جامعت المنصورة } \\
& \text { المجلد الثانى ـ العدد الرابع }
\end{aligned}
$$

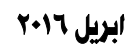




\section{مستوى الطموح لدى طلاب المرحلة الثانوية}

\section{الباحثتر عائشت فرج محمد المنشوف*}

\section{تمهيد:}

أن مستوى الطموح يلعب دورًا هامًا في حياة الفرد و الجماعة، و إنه أحد المتغيرات ذات التأثير البالغ في ما يصدر عن الإنسان من نشاط، ولعل الكثثر من انجاز ات الأفر اد وتقدم الأمم و الثعوب يرجع إلى توفير القدر المناسب من مستوى الطموح، بالإضافة إلى توفر العوامل الأخرى التي تساعد على هذا الإنجاز و التقدم، هذا فضلاً عن ارتباط مستوى الطموح بالكفاية الإنتاجية، حيث إنه دن المعروف أن الكفاية الإنتاجية - كمًا ونوعًا- نزتبط ارتباطاً إيجابيًا بالمستوى العالي من الطموح، كما يعتبر مستوى الطموح علامة هامة من علامات الروح المعنوية سواء بالنسبة للفرد أو الجماعة."كامليا عبد الفتاح، $176: 199$.

ويلعب مستوى الطموح دورًا فعالاً في حياة الفرد، فهو أحــد المتغيـر ات

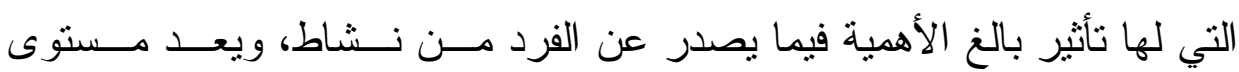
الطموح من المصطلحات الثائعة بين الباحثين و الدارسين لما له من أهمية فـي تتمية وتقدم الأفر اد و المجتمعات."محمد نايف عياصر ه، برهان محمود حمادنــة، "Yrצ:

$$
\begin{aligned}
& \text { "بحث مستخلص من رسالت ماجستير للباحث }
\end{aligned}
$$

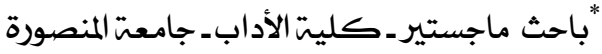




\section{مفهوم مستوى الطموح:}

تشير "كامليا" للوصول إلى تحديد مفهوم مستوى الطموح لابد أن نتعرض

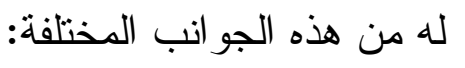

1) مستوى الطموح باعتباره استعدادًا نفسيًا:

و المقصود بالاستعداد النفسي بالنسبة لمستوى الطموح، أن بعض النـاس عندهم الميل إلى تقدير وتحديد أهدافهم في الحياة تقديرًا يتسم إما بالطموح الز ائد

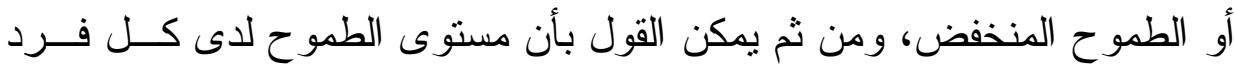
ينأثر بالعو امل التكوينية وعو امل التدريب و التربية و التتشئة المختلفة. r r مستوى الطموح باعتباره وصفًا لإطار تقدير وتقويم الموقف: ويتكون هذا الإطار من عاملين أساسين:

الأول: التجارب الثخصية من نجاح وفثل التي يمر بها الفرد و التــي تعدـل على تكوين أساس يحكم به على مختلف المو اقف و الأهداف. الثاني: أثز الظروف و القيم و التقاليد و العادات و اتجاهات الجماعة في تكـــين

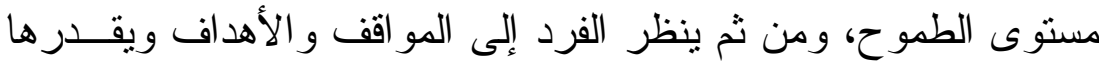
ويقيمها من خلال هذا الإطار الحضاري العـام و التجربــة الثخــصنية

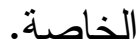

ץ") مستوى الطموح باعتباره سمة:

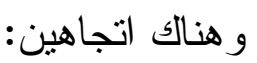
الأول: نجد أن الفرد الطموح يكون طموحًا في كافـــة المواقـــــ والظــروف

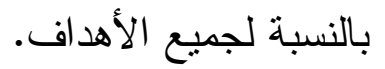


الثاني: نجد أن الفرد الطموح يكون طموحًا في بعض المو اقف دون غيرهــا

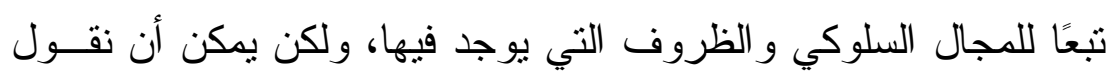

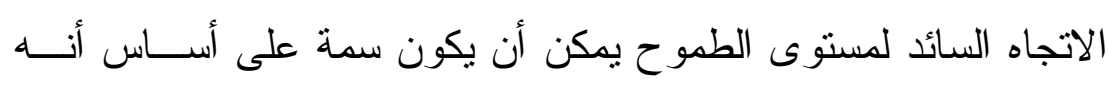

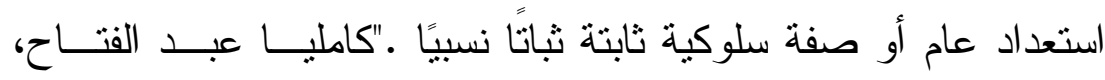

$$
\text { "1 } 14-1 \text {. :199. }
$$

\section{تعريف مستوى الطموح:}

نتنتاول تعريف الطموح - كما عرفه مجموعة مسن البـاحثنين عرضـتهم

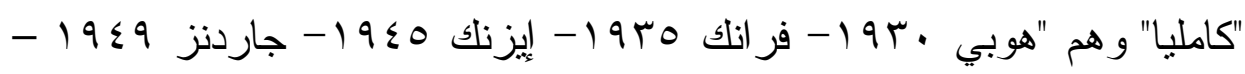

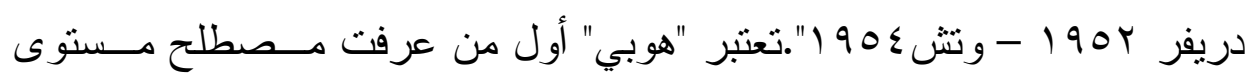

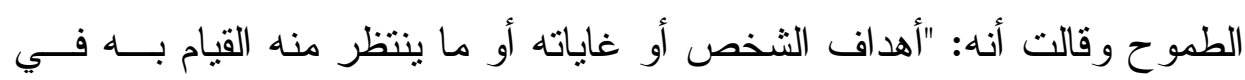

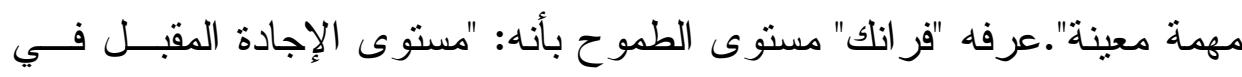

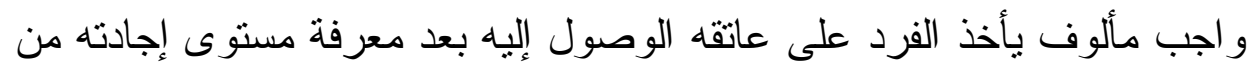
قبل في ذلك الو اجب.

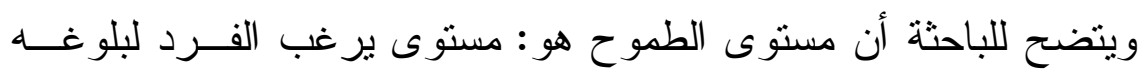

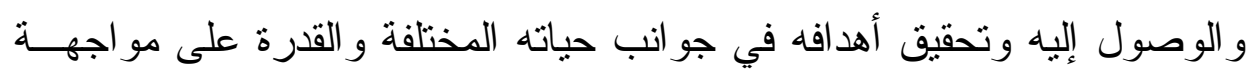

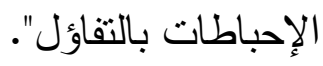

\section{نمو مستوى الطموح: - ت ن}

نجد أن عامل النمو يبدأ بمر احل مختلفة من الطفولة المبكرة حتـى آخــر

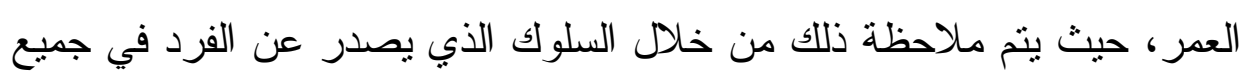

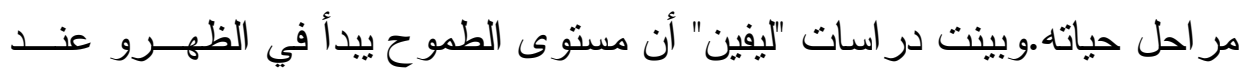

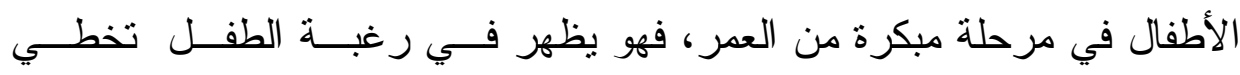

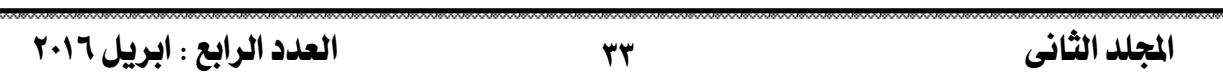


الصعوبات متل محاولته أن يقف على قدميه غير مستعين بأحد أن بمشي وحده،

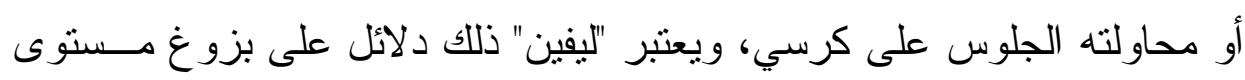

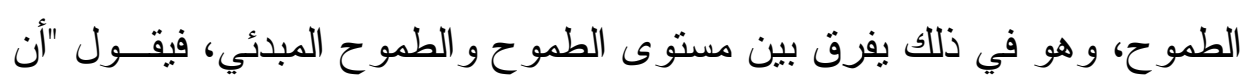

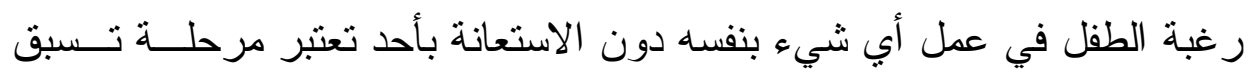

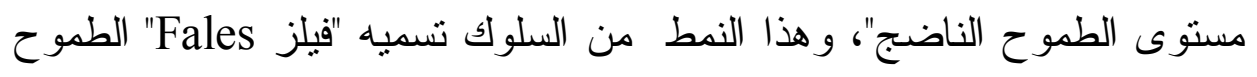
المبئي Rvdimentary Aspiration

وقد استطاع "اندرسون Anderson" أن يثبت من خلال در استه المتعـددة

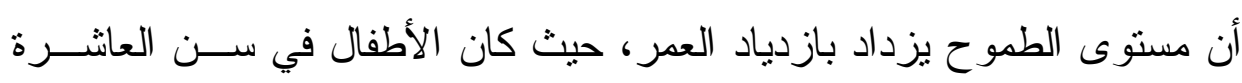

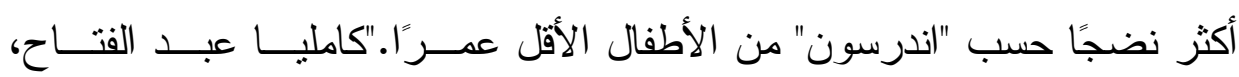

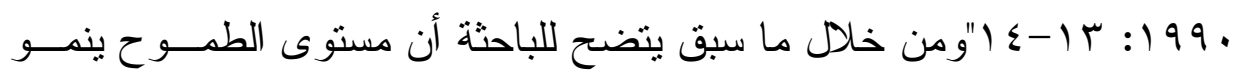

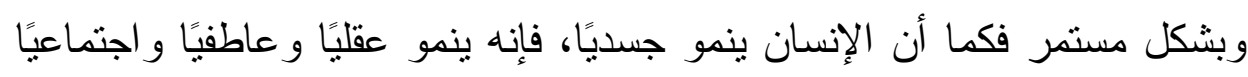

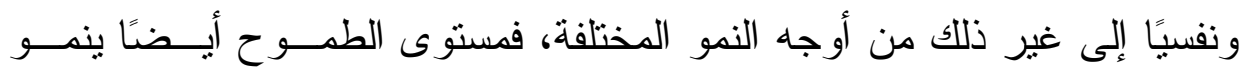

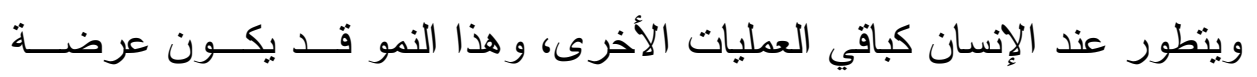

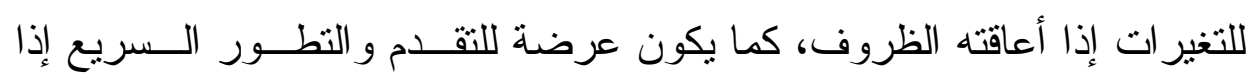
ساعدته الظروف على ذلك.

العوامل المؤثرة في مستوى الطموح: 1) - (العو امل الذاتية:

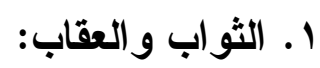

إن الأثر الطيب يثبت الاستجابة الصحيحة، ينتشر إلى الاستجابة الخاطئــة

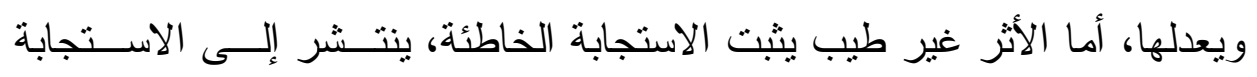

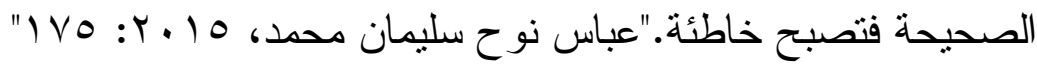




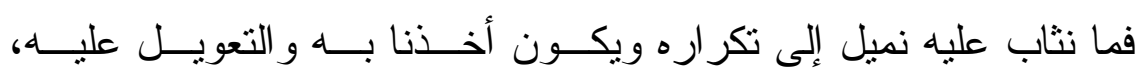

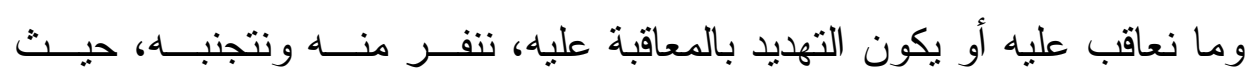

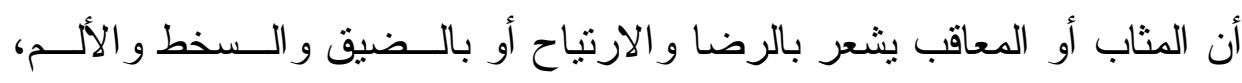

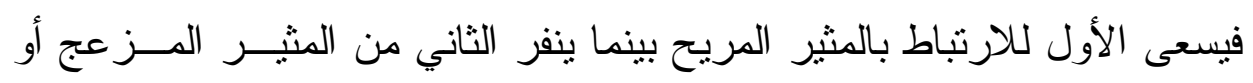

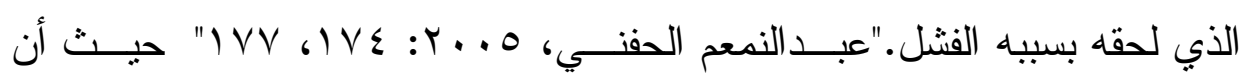

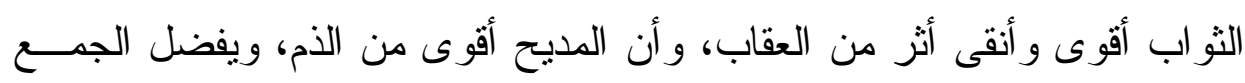

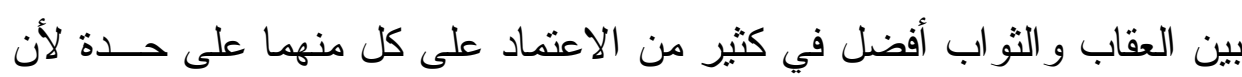

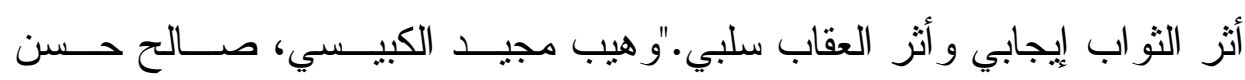

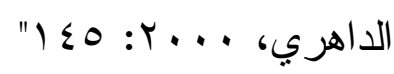

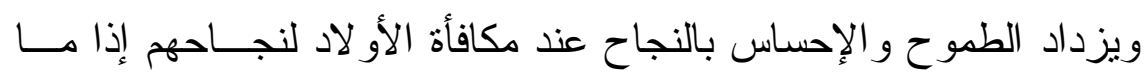

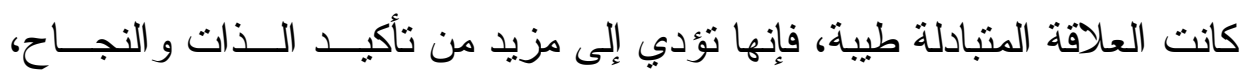

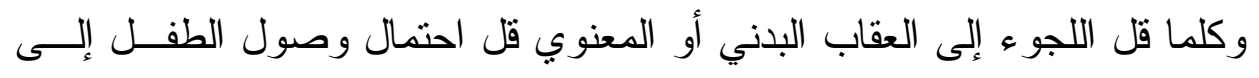

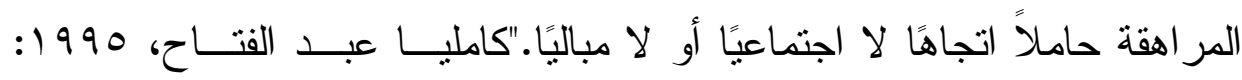

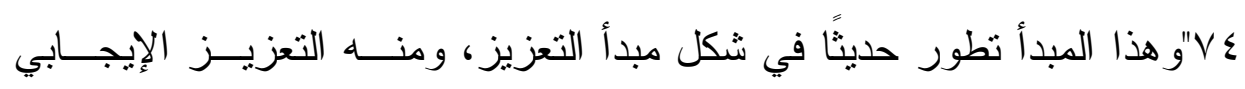

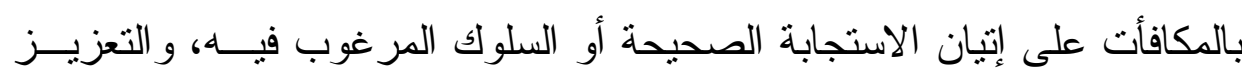

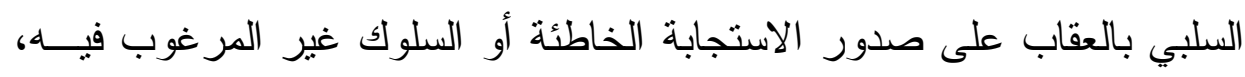

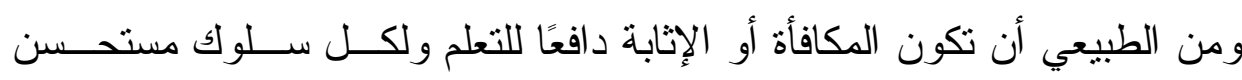

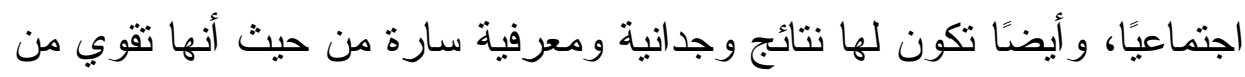

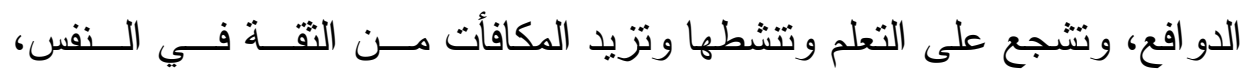

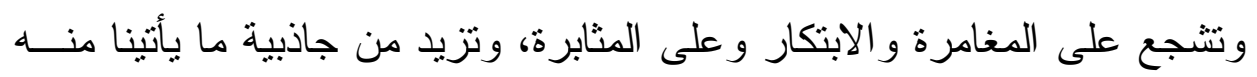

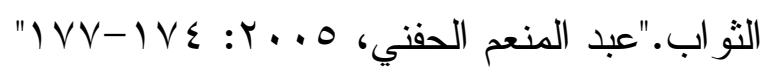


وقد أكدت "فيلز" أن المديح وهو - تعزيز لفظي - كان له أثر فعال فـي

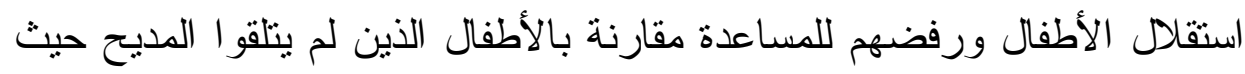

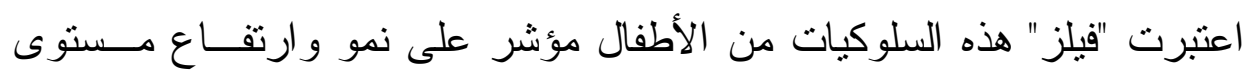

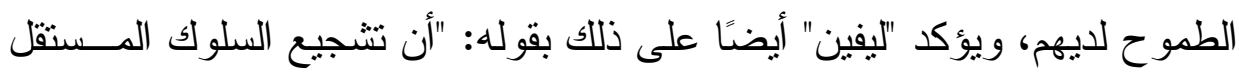

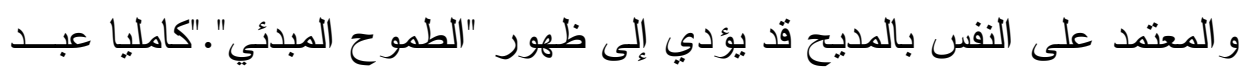

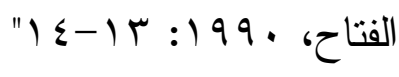

فالتعزيز أو المكافأة من المبادئ الهامة التي تـسهل عمليــة الــتعلم، أي أي

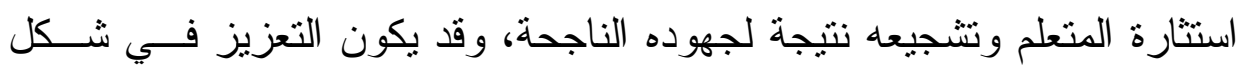

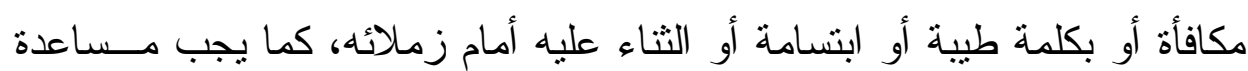

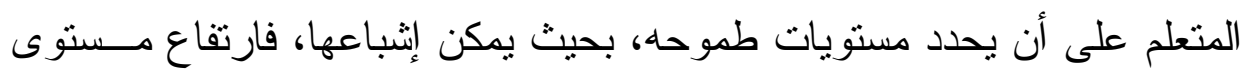

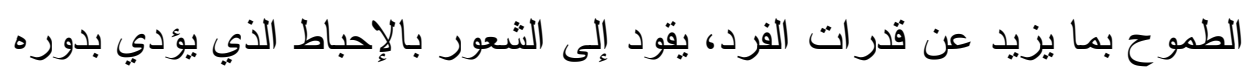

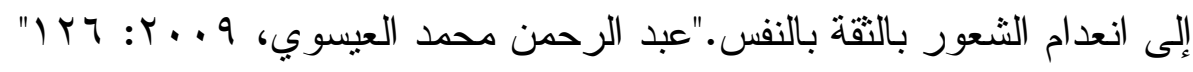

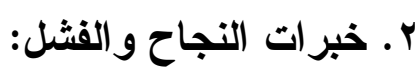

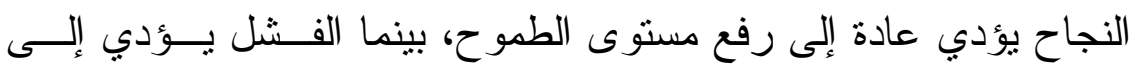

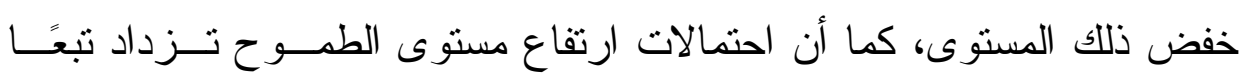

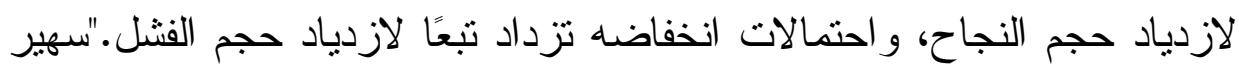

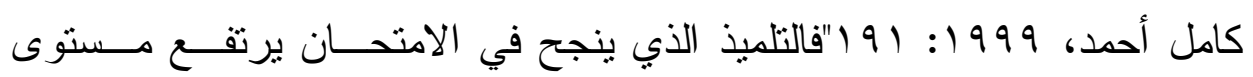

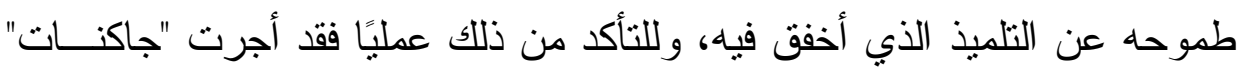

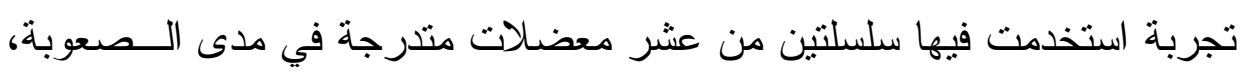

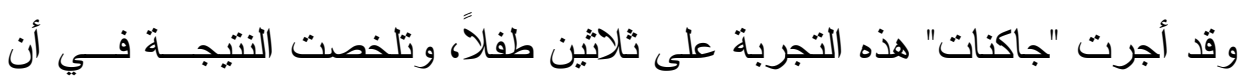
السلسلة التي يمكن حلها أدت إلى ارتفاع مسنوى الطموح من مستوى يبدأ مسن 


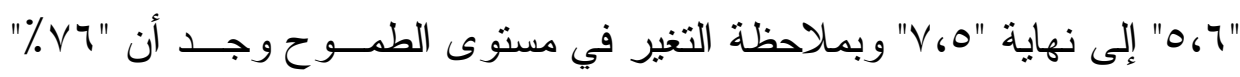

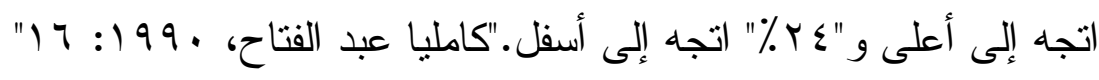

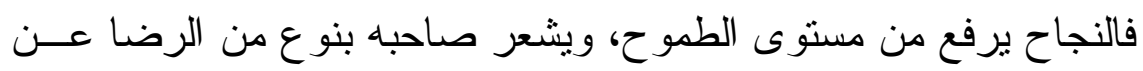

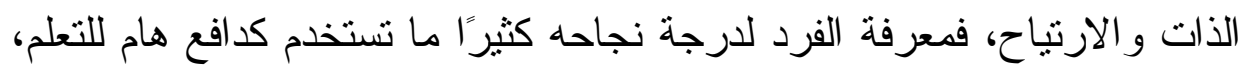

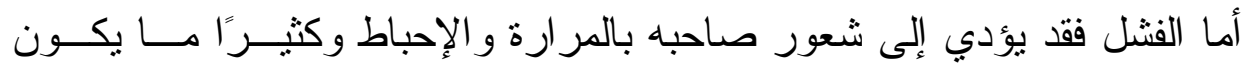

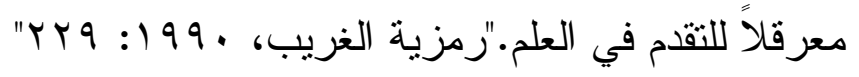

فالتلميذ عندما ينجح ويدرك مقدار ر نجاحه "مرتفعًا أو منوسطًا أو ضعيفًا"

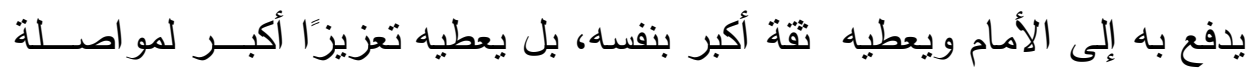

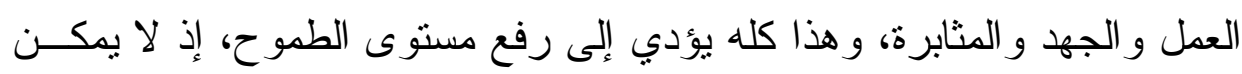

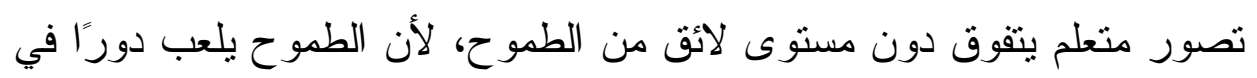

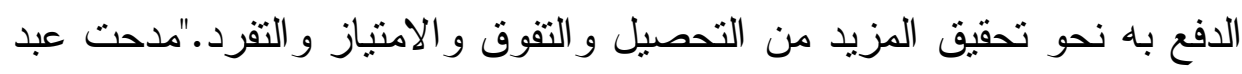
الحميد عبد اللطيف، 1999: 117 11

فإن تذوق الأبناء معنى النجاح سعو ا للوصول إليه ويعتبر "دكتور ميسرة"

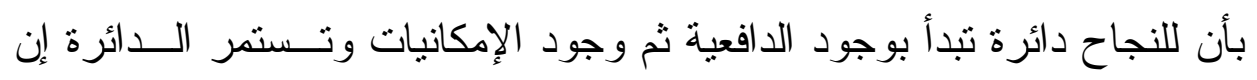

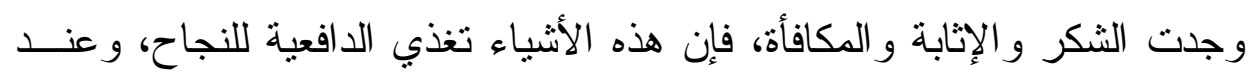

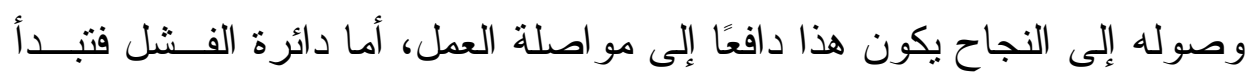

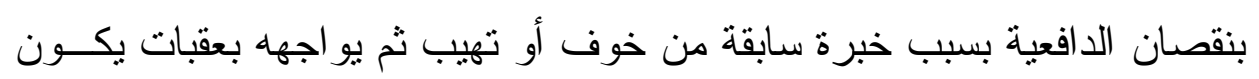

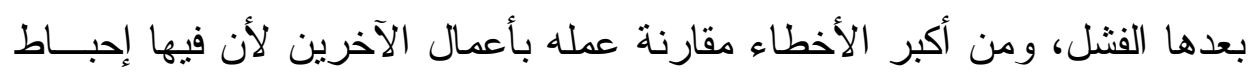

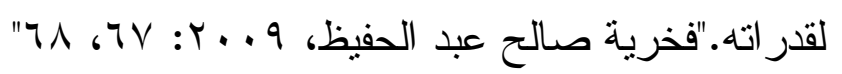


يرى "روجز" أن الفرد لديه دافع أساسي يوجه سلوكه وهو دافع لتحقيــق

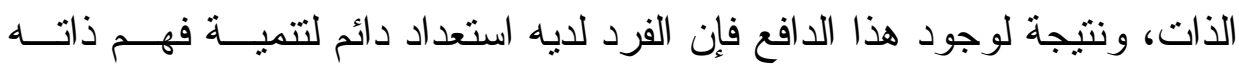

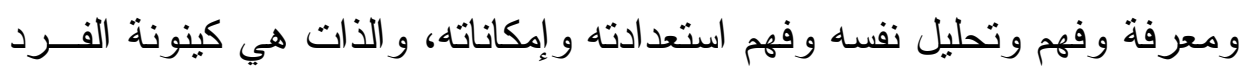

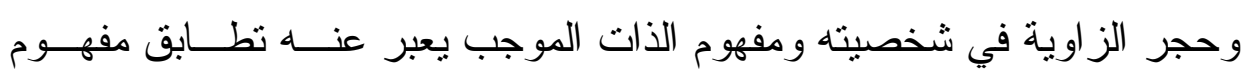

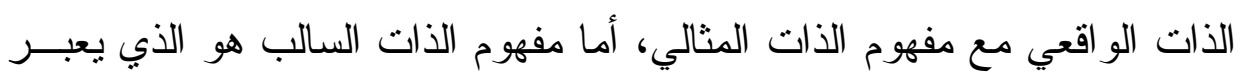

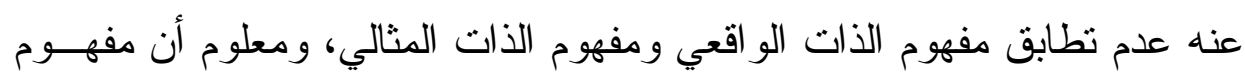

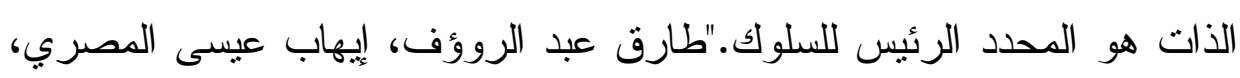
"OV: Y. I

كما ويتوقف ذللك على الصورة التي يكونها الفرد لنفسه، فمثناً هل يــرى

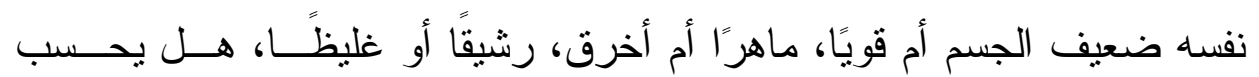

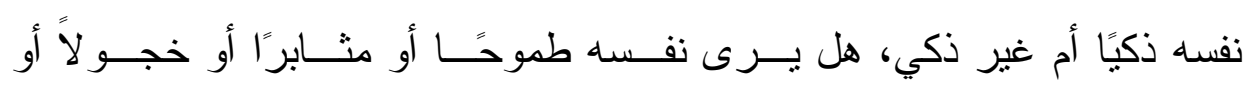

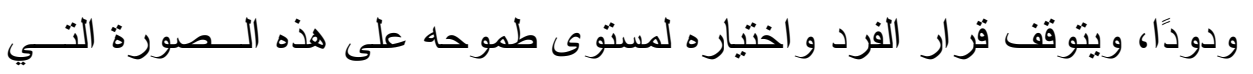

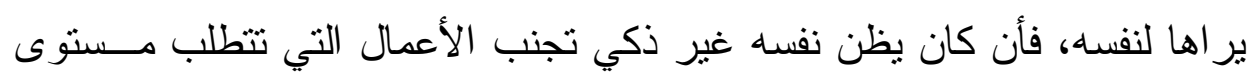

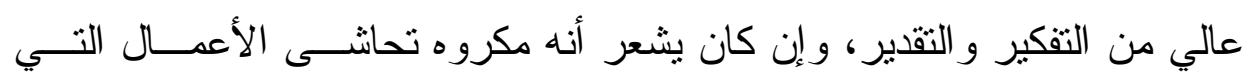

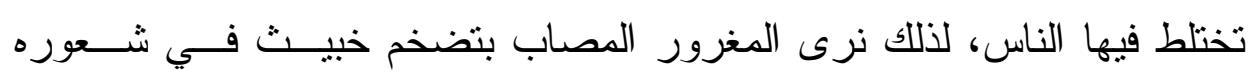

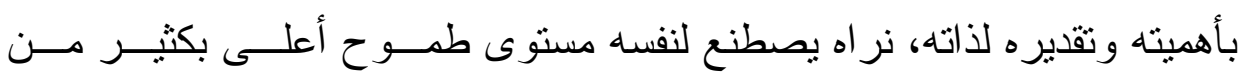

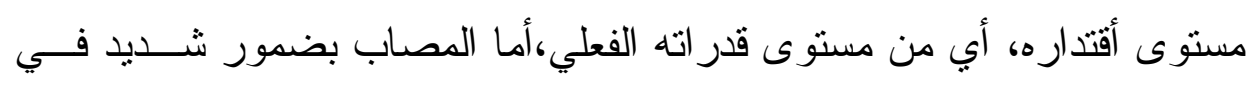

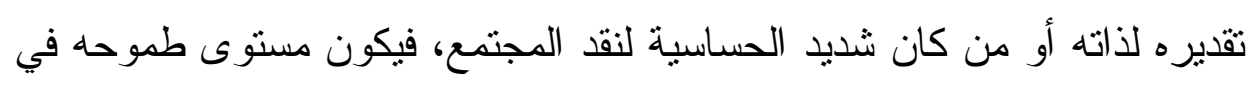

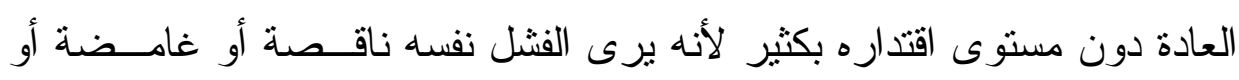

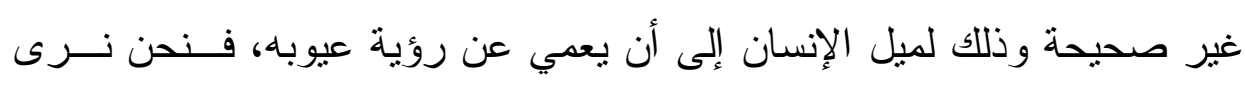


أنفسنا كما تحب لا كما هي في الو اقع لكنها عامل بالغ الأثر في توجيــه ســلوكه

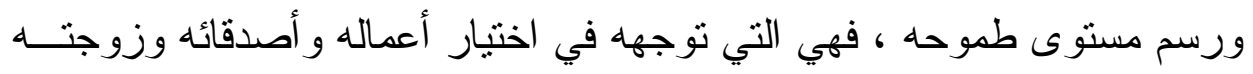

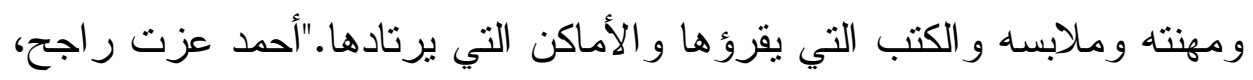
"1 1 1-1r.: 199

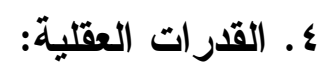

تؤكد (رمزية الغريب) أن مستوى الطموح ودرجته يتوقف علــى قـدرة الفرد العقلية، فكلما كان الفرد أكثر قدرة كان بمقدرة القبام بتحقيق أهداف أبعـد الفيد

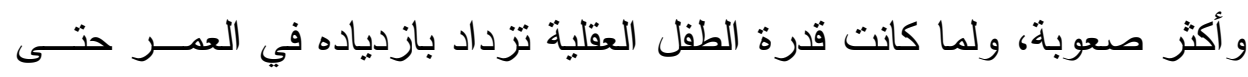
يصل إلى مستوى معين، فإن مستوى طموح الطفل يتغير بتغير عمره الزمنــي."

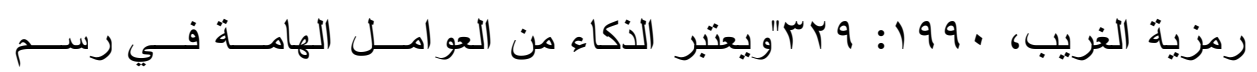

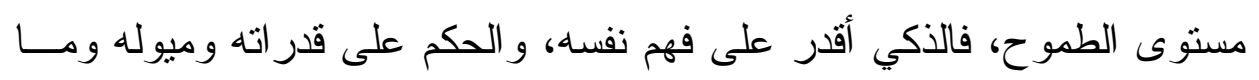

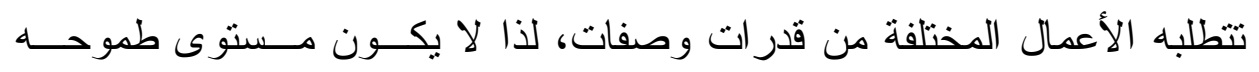

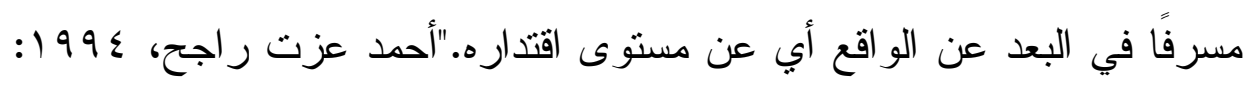

كما وتعد نسبة الذكاء ضرورية للنجاح في عملية التعلم، إذ كلهـا ازدادت

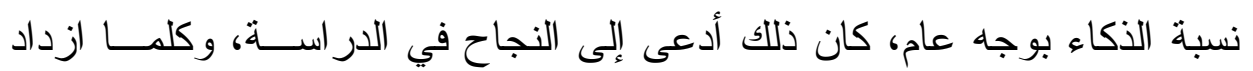

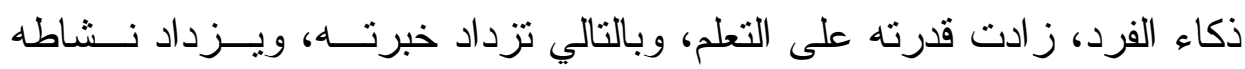

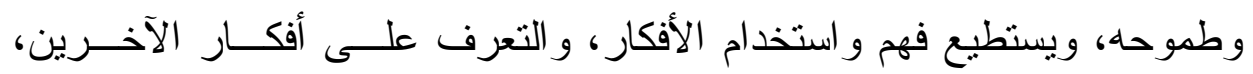

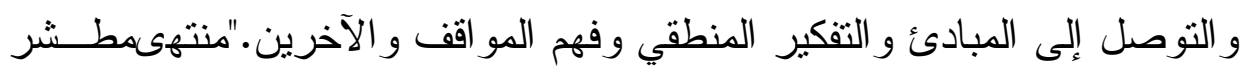

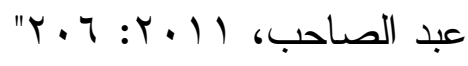


الثخص السوي هو الذي يضع نصب عينيه مستويات يـسعى للوصــول

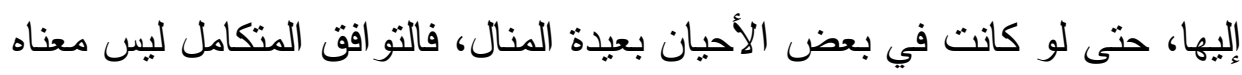

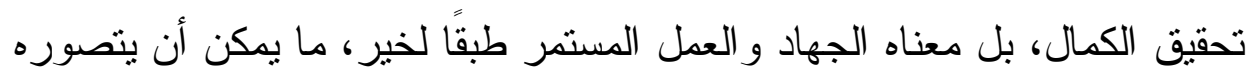

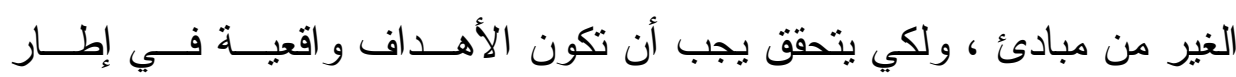

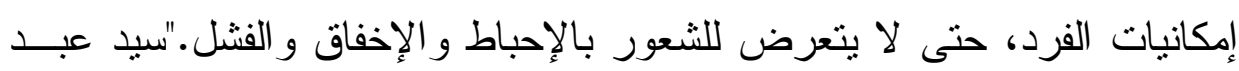

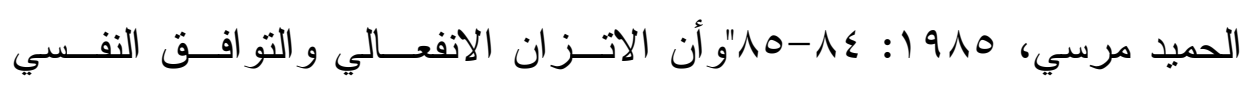

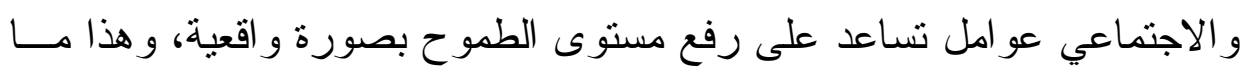

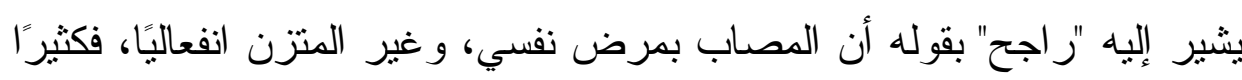

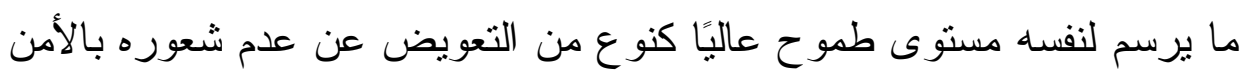

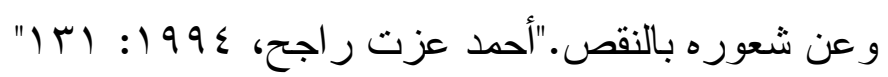

ودر اسة مستوى الطموح قد تلقي الضوء على أسباب الاضطر اب النفسي

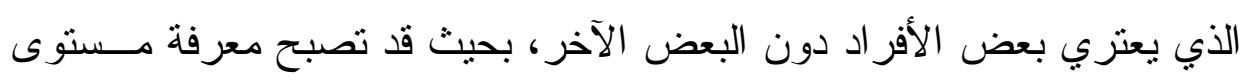

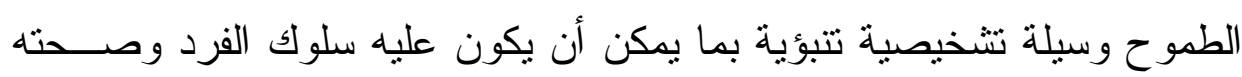

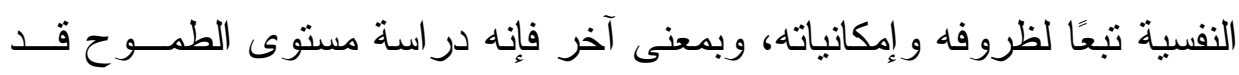

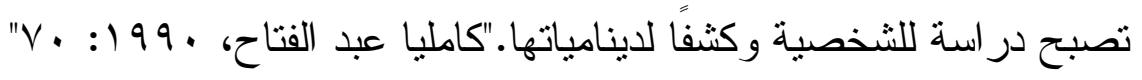

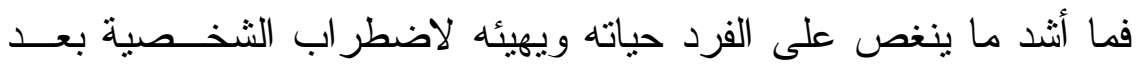

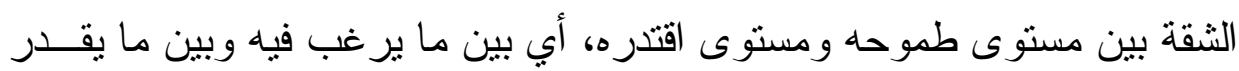

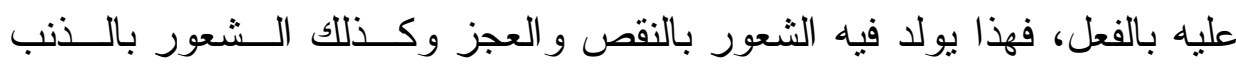

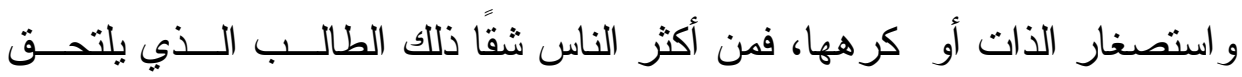

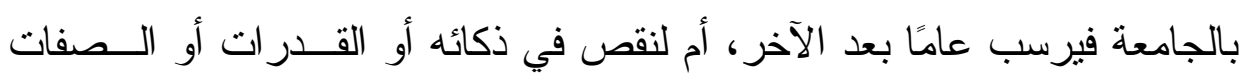




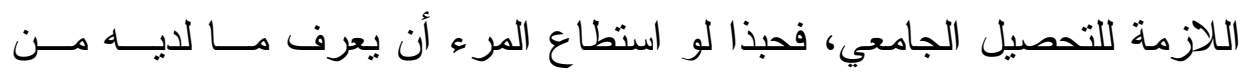

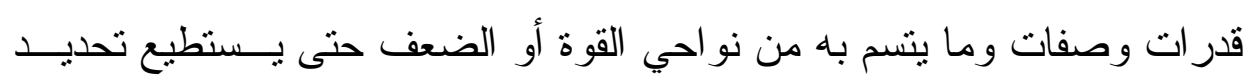

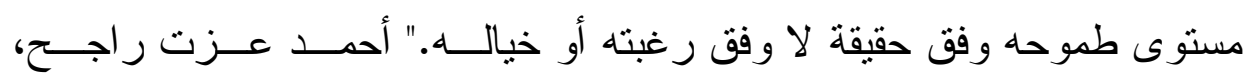

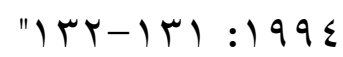

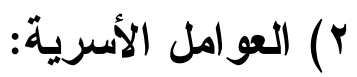

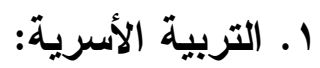

للأسرة وظيفة اجتماعية ونفسية هامة، فهي المدرسة الأولى للطفل، وهي

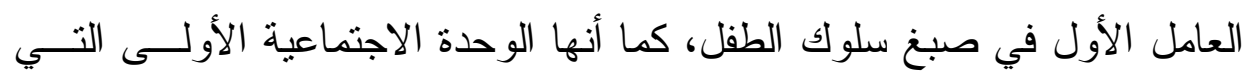

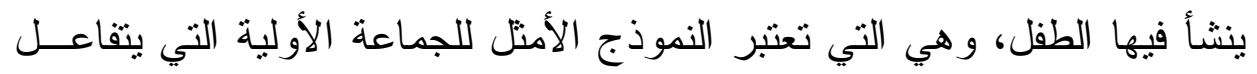

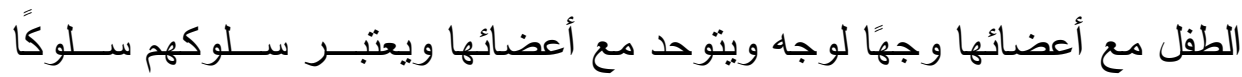

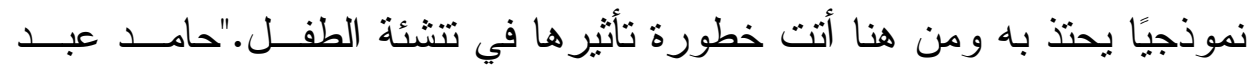

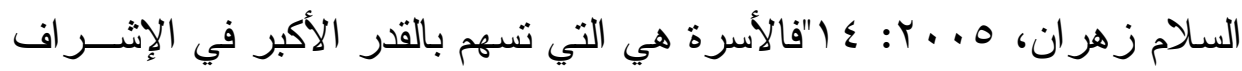

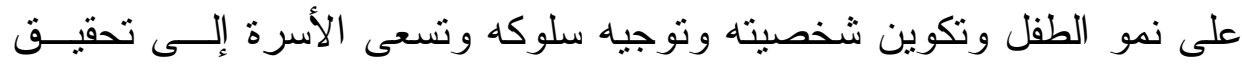

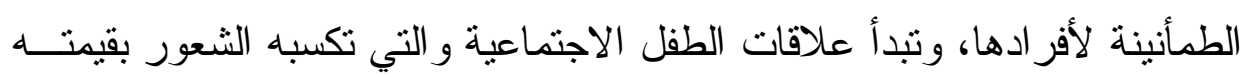

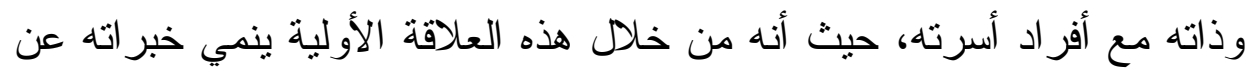

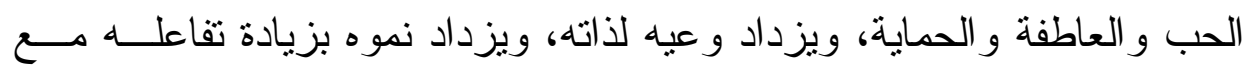

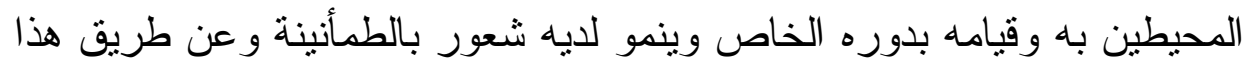

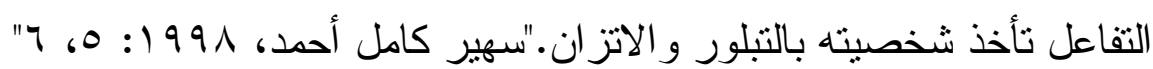

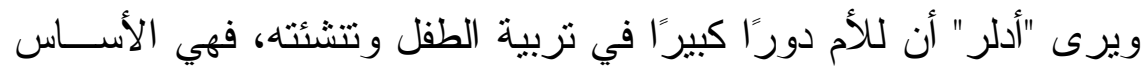

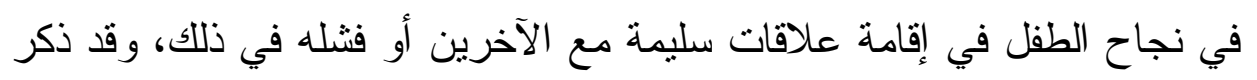

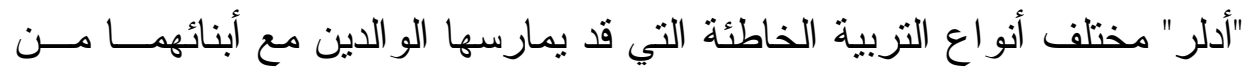




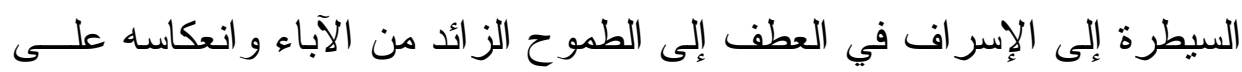

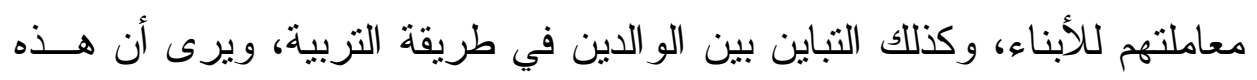

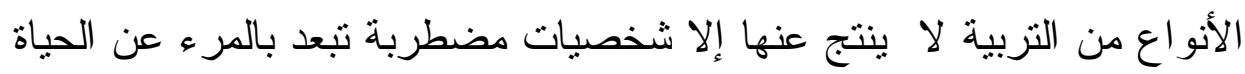

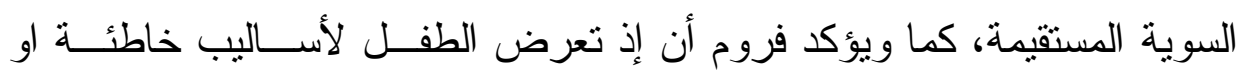

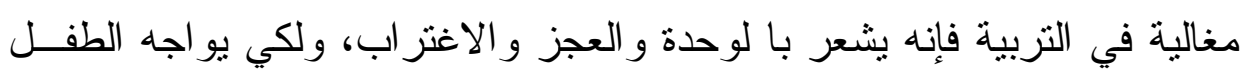

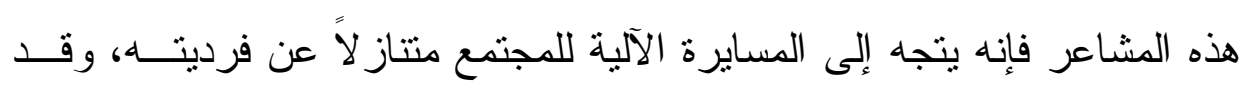

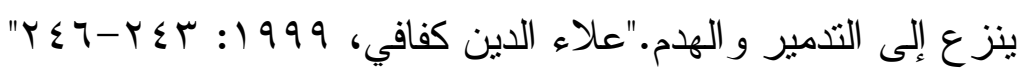

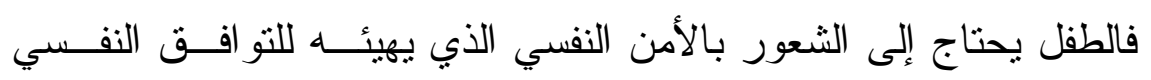

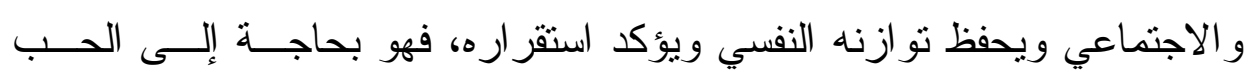

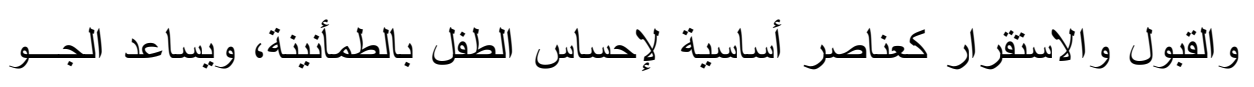

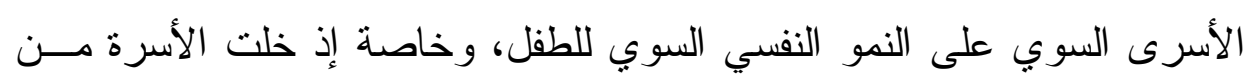

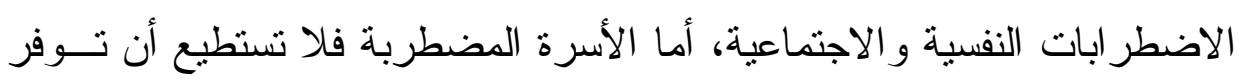

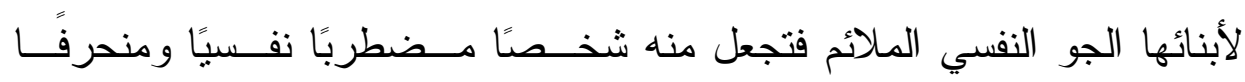

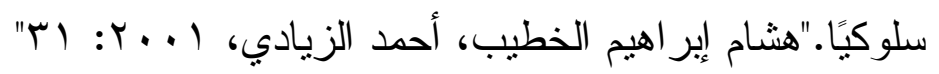

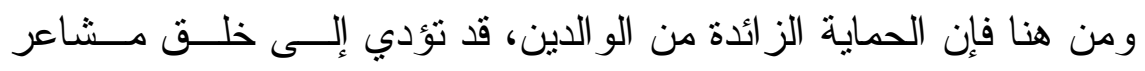

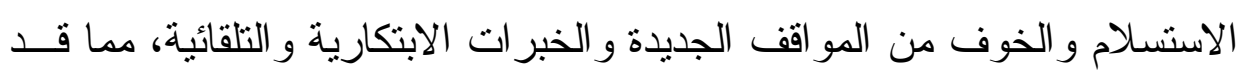

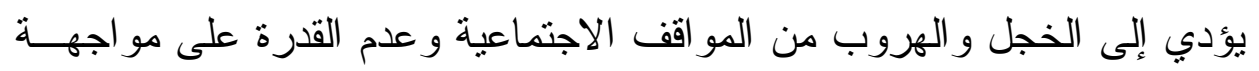

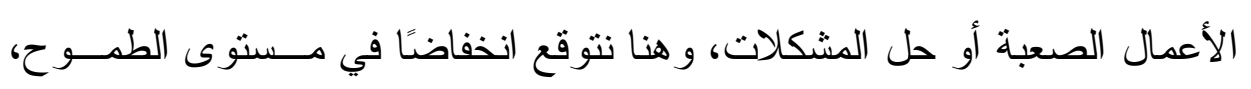

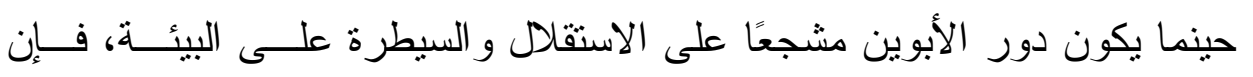

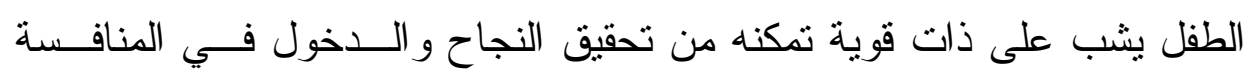




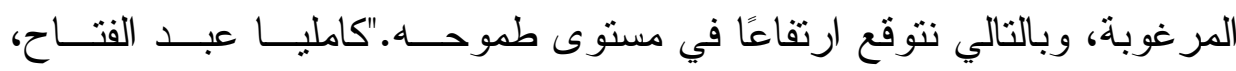
$109: 199$.

\section{r ب. المستوى الاجتماعي و الاقتصادي للأسرة:}

تدل در اسات "بلوكسا" على أن للمسنوى الاقتصادي و الاجتماعي للأســرة

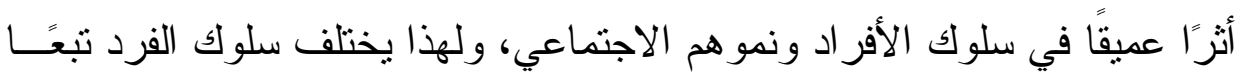

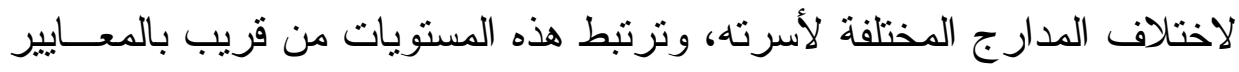

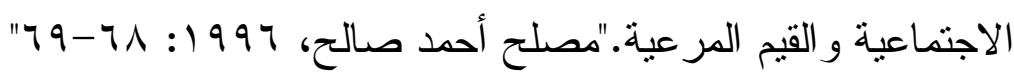

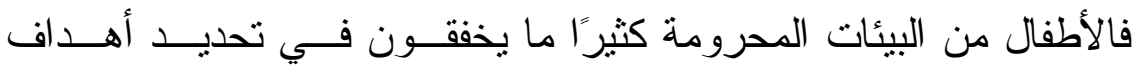

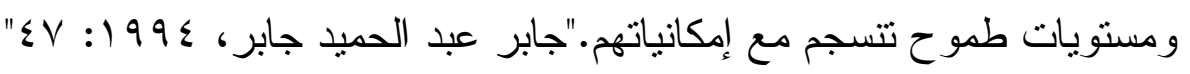
وييدو أن الظروف الاقتصادية وما يو اجه الأمم من تحديات يرفــع مـن

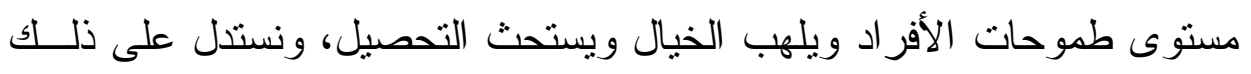

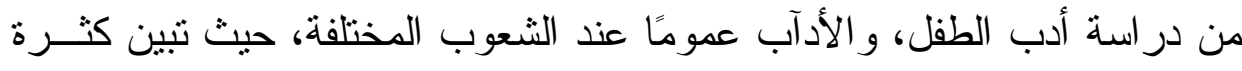

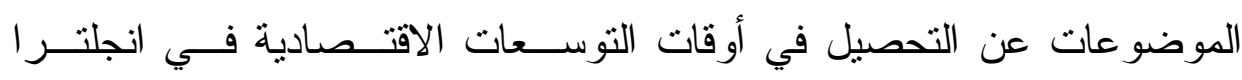

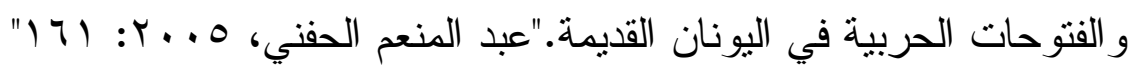
ويشير "سكوبيل و آخرون" إلى أنه إذا كان الهدف من الصحة النفسية فـي

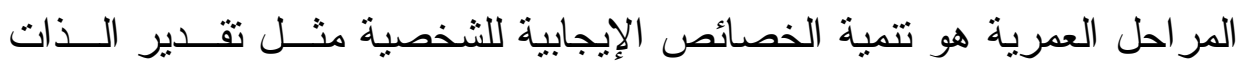

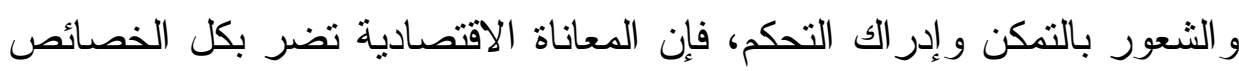

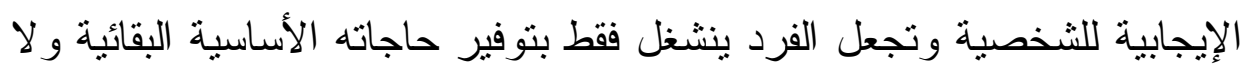

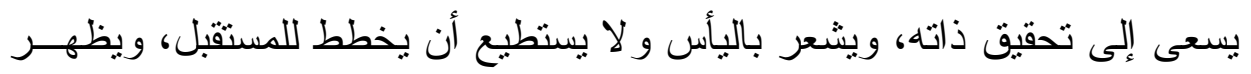

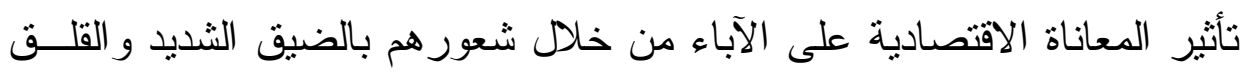

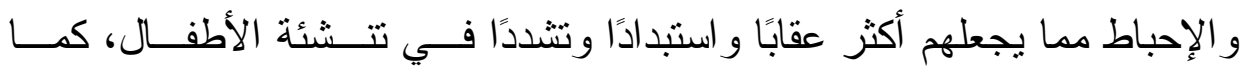


ويصبح الأب أكثر حساسية ويقل لديه مستوى الطموح ويزداد لايه الثعور بعدم

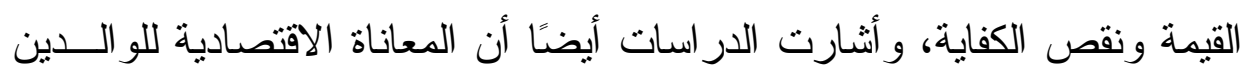

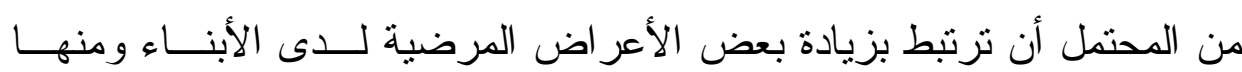

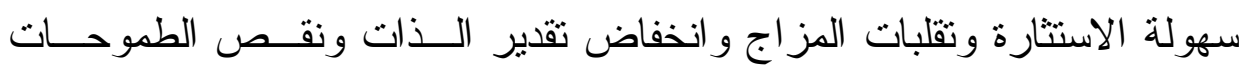

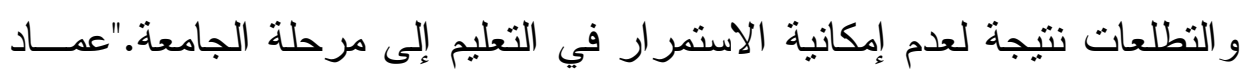

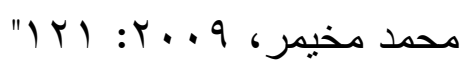

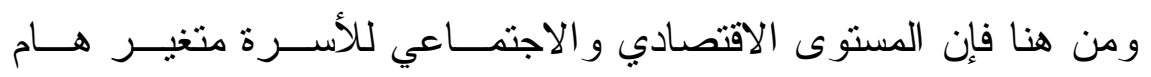

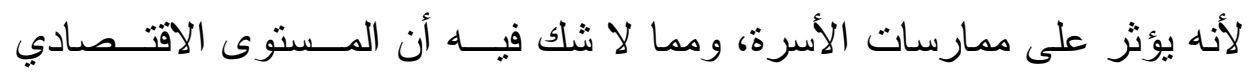

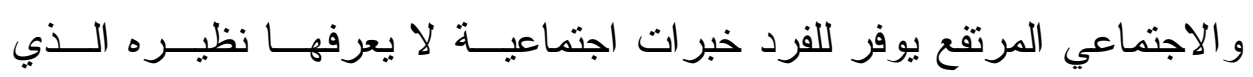

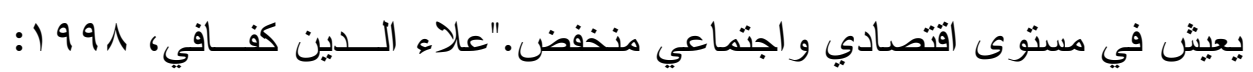
"10T

ففي بحث الدكتور "جوزيف انطون" نستتنج أن النسبة العظمــى للتناميــذ

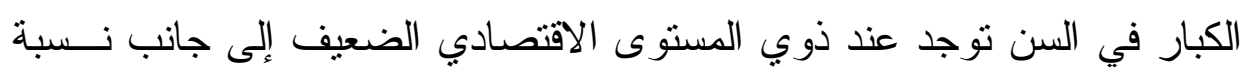

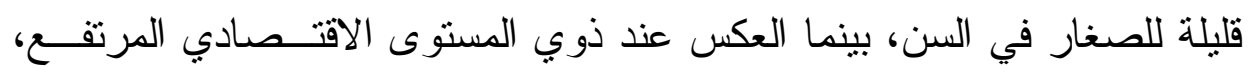

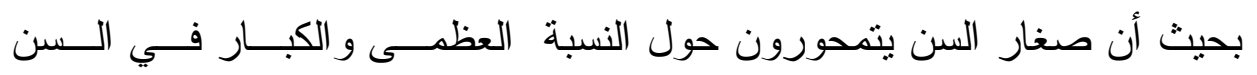

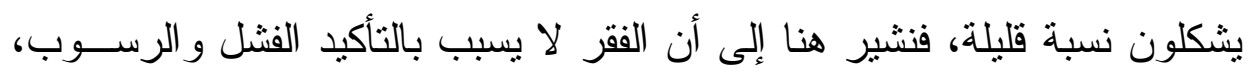

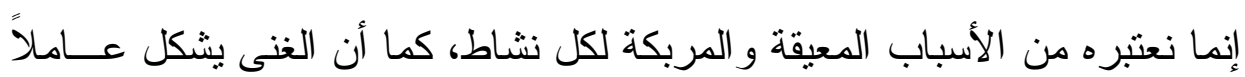

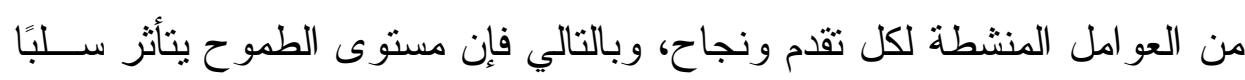

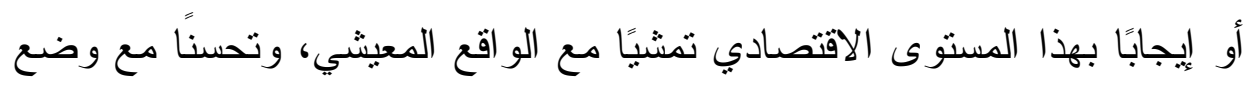

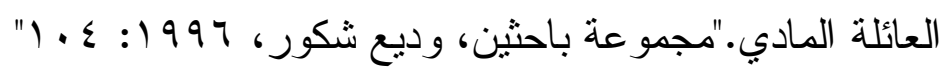


أن طموح الو الدين و الأهل عنصر هام وأساسي في تشكيل شخصية الطفل

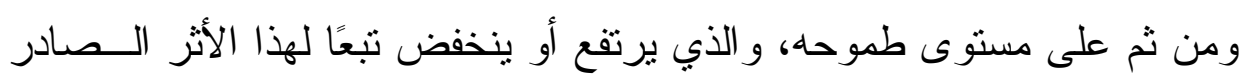

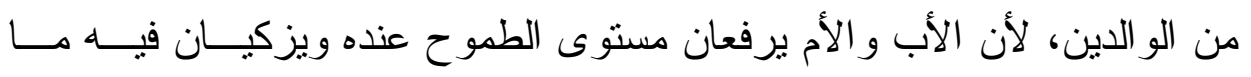

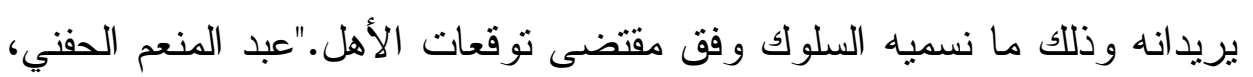
" . $9:$ : . . ०

وتؤكد كامليا أن طموح الو الدين قد يلعب دورًا خطيرًا في زيادة طهـوح

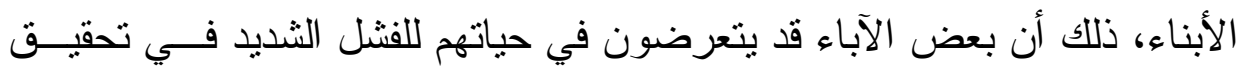

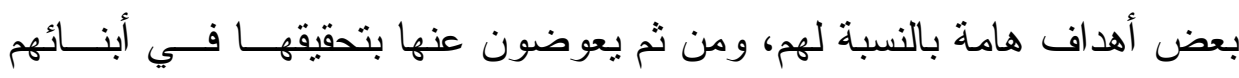

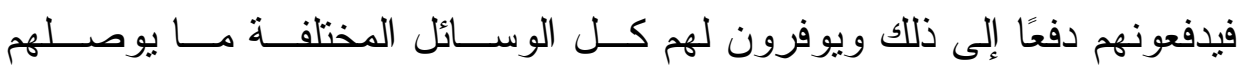

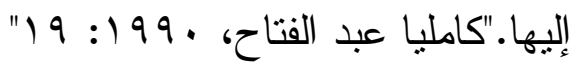

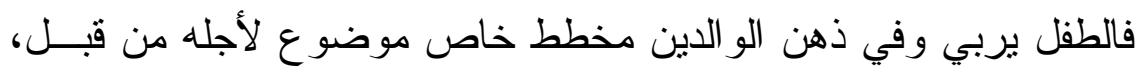

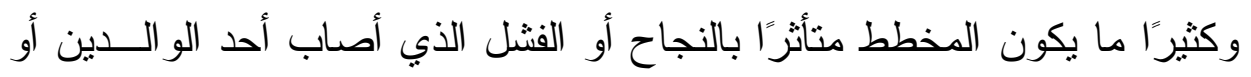

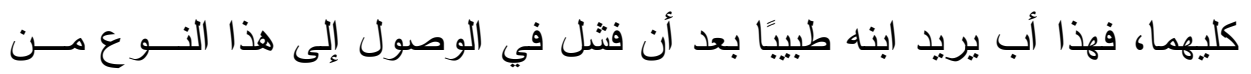

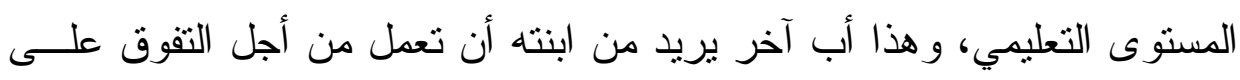

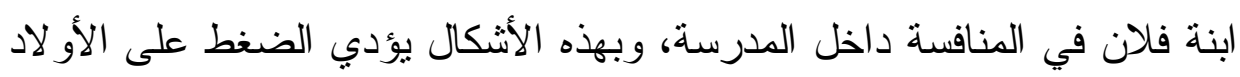

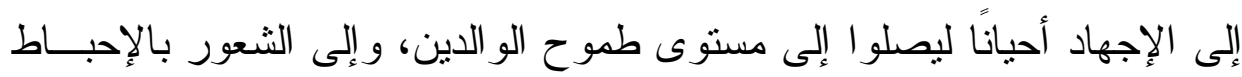

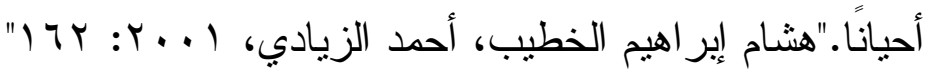
ومن هنا فإن مستوى الطموح لاى الطفل يتأثزر إلى درجة كبيرة بالأهــل،

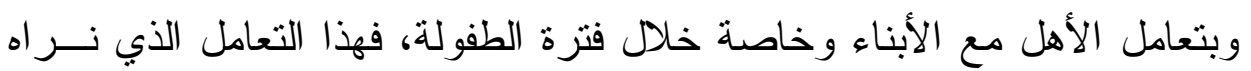

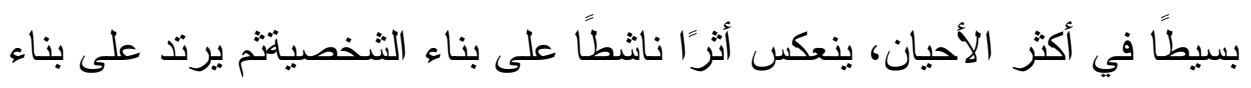




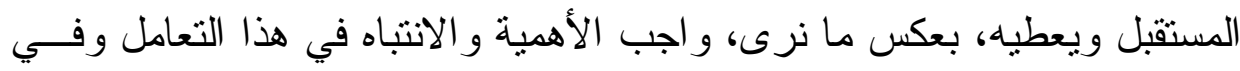

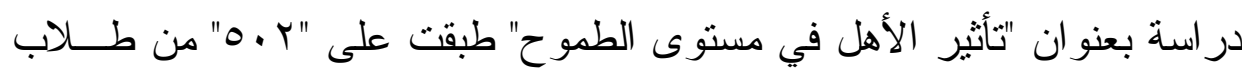
المتوسط الر ابع في ثلاثة و عشرين مدرسة تكميلية، وجد أن إثارة الأهل لابنائهم

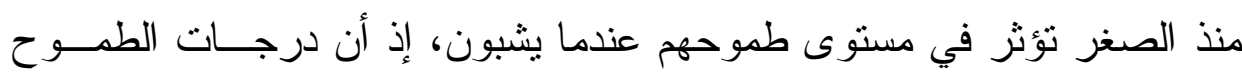

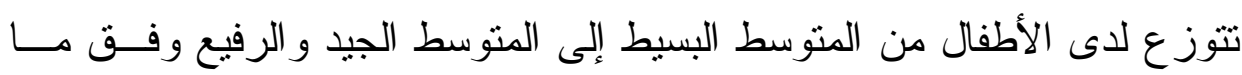

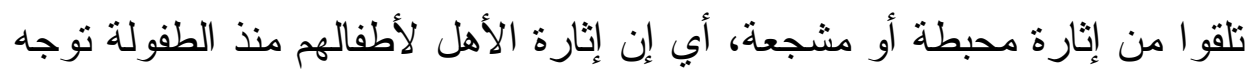

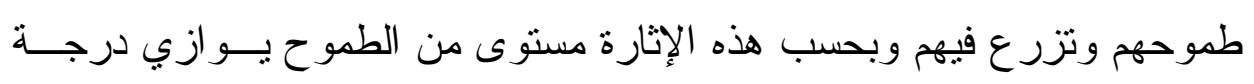

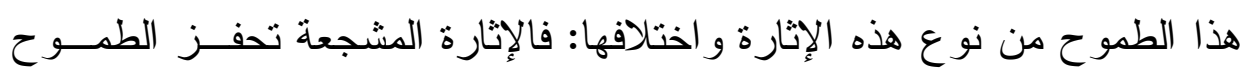

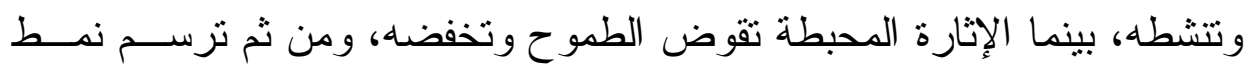

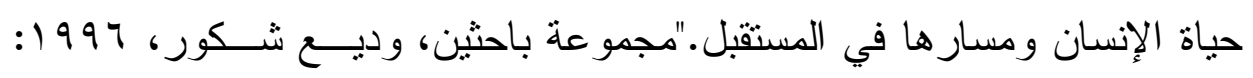

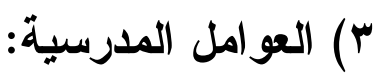

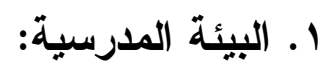

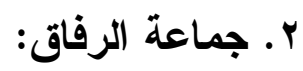

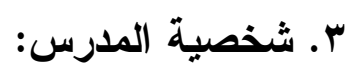

\section{سمات الشخص الطموح:}

1. مغامر، يحب المنافسة ويتحمل المسئولية.

r. لا يقنع بالقليل و لا يرضى بالوضع الر اهن ويعمل دائمًا على النهوض به،

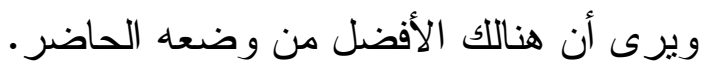
r. لا يؤمن بالحظو لا يترك الأمور تسير بمحض الصدفة. 
؛. لا يخشى الفشل و المجهول ويتحمل المخاطر و الأهو ال.

○. لا ينتظر حتى تأتيه الفرصة فأمل الثخص الطموح في تز ايد.

7. لا يغضب من تأخر نتائج أعماله فهو متأكد بأن الصعاب يمكـن تـــليلها

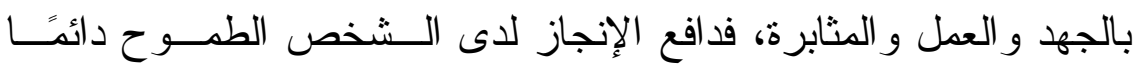

$$
\text { مرتفع. }
$$

V. يتحمل الصعاب في سبيل الوصول لأهدافه ولا يعنيه الفشل لأنه لا يشعر

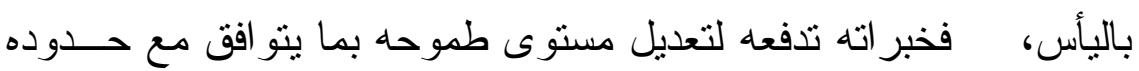

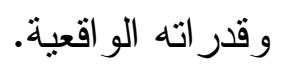

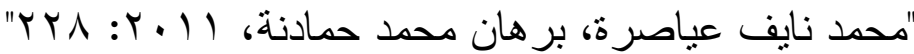

وترى الباحثة مجموعة أخرى من الخصائص التي ينسم بهـــا الــشضص

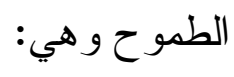

ا . يحدد أهدافه وخططه المستقبلية بشكل مناسب.

$$
\text { r. r. بحب الخير ومتعاون مع الجماعة. }
$$

ع. يؤمن أن جهد الإنسان و عمله هو الذي يحدد نجاحه في أي مجال.

$$
\begin{aligned}
& \text { ○. يعتمد على نفسه في إنجاز المهام الخاصة به أو بأسرته. } \\
& \text { النظريات المفسرة لمستوى الطموح: }
\end{aligned}
$$

لقد اختلفت النظريات النفسية في تفسير مستوى الطموح بحسب الجانـبـ الذي ركزت عليه هذه النظريات و التي نستعرضها فيما يلي: 
( ) نظرية القيمة الذاتية للههف:

قدمت "أسكالونـEscalona • 9 1" نظرية القيمة الذاتية للهـدف وتــرى

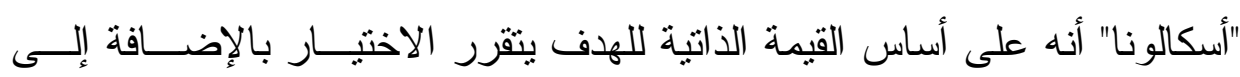

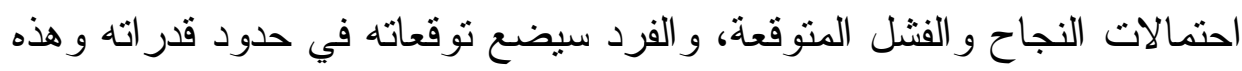
النظرية تحاول تفسير ثالاث حقائق وهي:

ا. . هناك ميل لدى الأفر اد للبحث عن مستوى طموح مرتفع نسبيًا. r. كما أن لديهر ميلاً لجعل مستوى طموح يصل إلى حدود معينة.

r. الميل لوضع مستوى الطموح بعيدًا جدًا عن المنطقة الصعبة جدًا والــسهلة

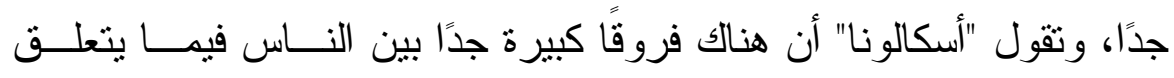

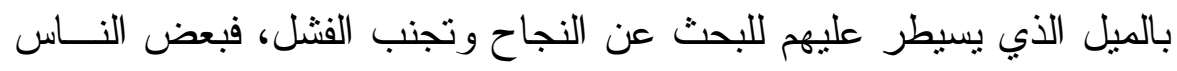

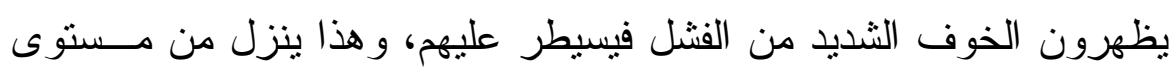

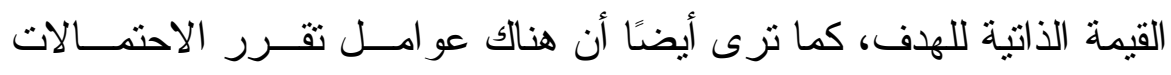

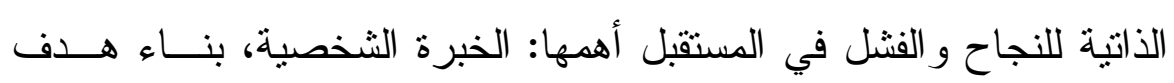

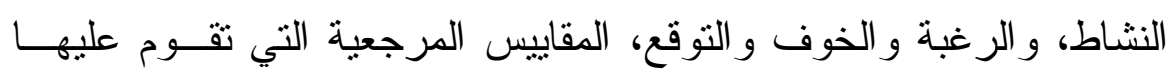

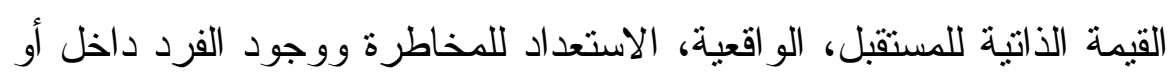

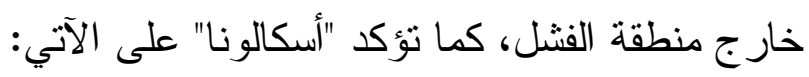

• الفثل الحديث يميل إلى إنقاص مستوى الطموح، و الحالات التي ترفحسه

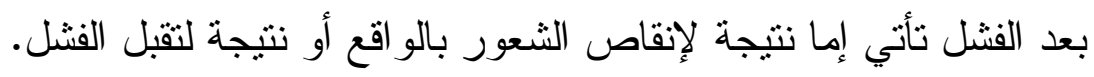

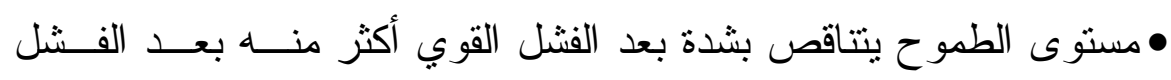
الضعيف، ويتز ايد بعد النجاح. 
• الثخص المعتاد على الفشل يكون لديه درجة اختلاف أقلىـن الـشخص الذي ينجح دائمًا. • البحث عن النجاح و الابتعاد عن الفشل هو الأساس في مستوى الطموح. "كامليا عبد الفتاح، • 199"

Yurtlevince نظرية المجال لكيرت ليفين يذكر ليفين عند كلامه عن أثز القوى الدافعة في التكوين المعرفي المجال

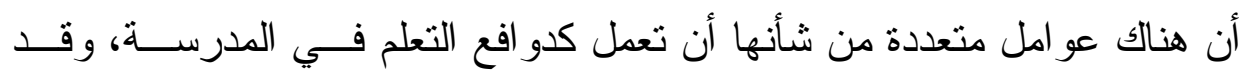

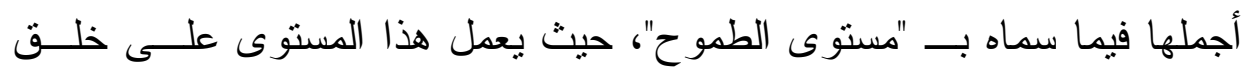

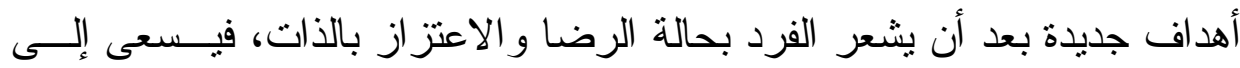

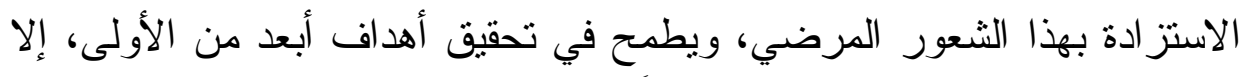

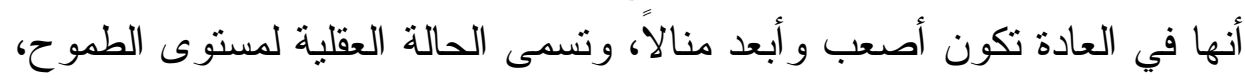

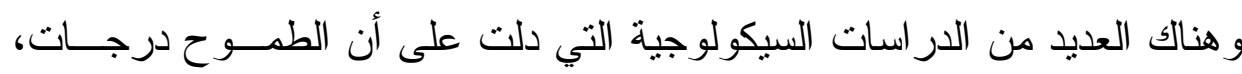

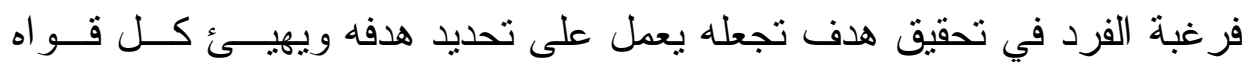

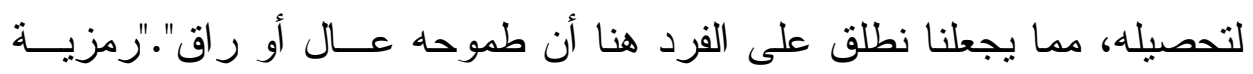

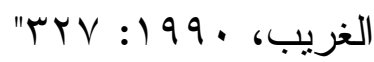

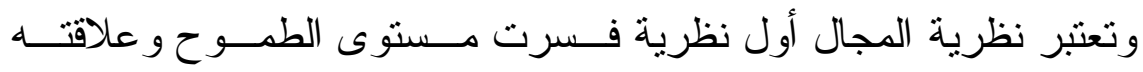

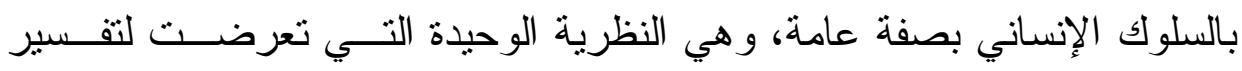

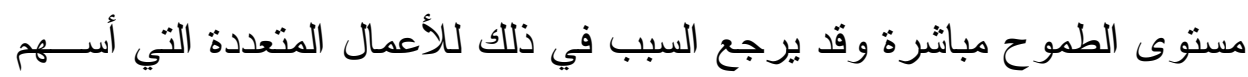

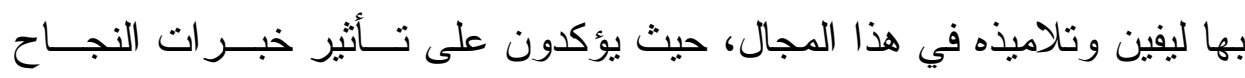

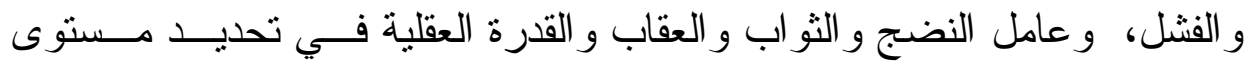

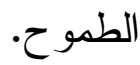

"كامليا عبد الفتاح، • 199 1: 
يرى "أدلر" أن محددات السلوك اجتماعية، وليست غريزية وتتركز علـى التى رغبة الإنسان في نوكيد الذات و التفوق، وفنل الإنسان في ذلك يثير لديه إحساسًا بالنقص.

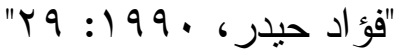

كما يؤكد "أدلر" على مفهوم القوة الخلاقة Power Creative ويعد هــذا

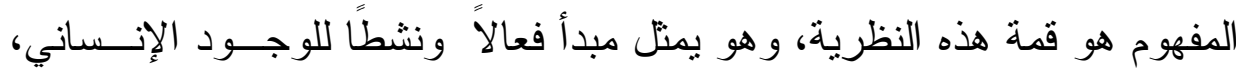

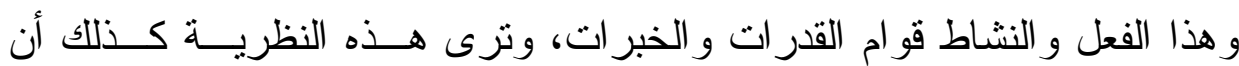
العو امل المؤثرة في الإنسان هي عو امل اجتماعية لها علاقة بالمحيط الذي يعيش

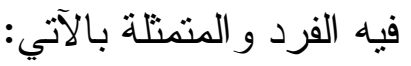
ا. التكوين الاجتماعي و المتمتل في العيش مع الجماعة وبالتـالي خـضضوع الفرد لمختلف أساليب ومبادئ التربية السائدة في البيئة التي يحيا فيها. r. رغبة الإنسان في الانتماء و الذي يؤدي بدوره إلى مساعدة الفرد لتكوين هويته. r. مركز الفرد في الجماعة التي ينتسب إليها، وتأثثير ذلك علـى مسستوى

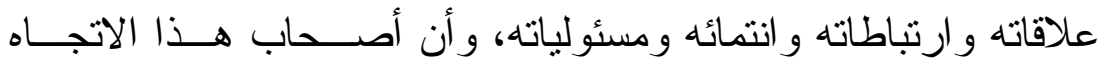

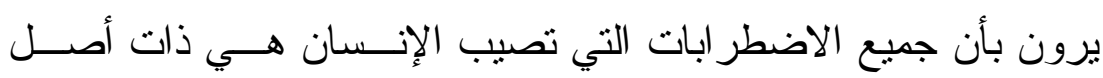
اجتماعي.

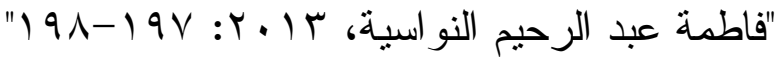


وكذللك من أهم أسس نظريته الثعور بالنقص والتعويض و النزوع نحو

التفوق أو السبطرة، والغائية التي تحكم عملية التعويض وكذلك أسلوب التهب الحياة

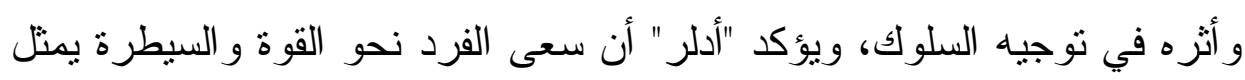

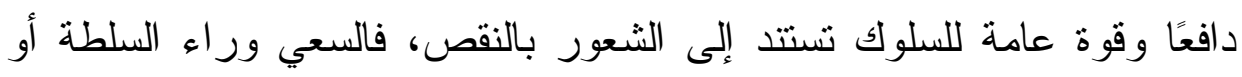

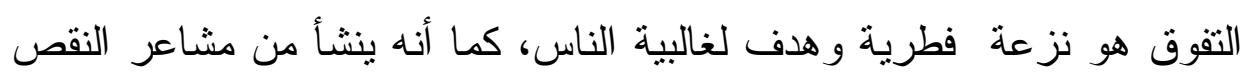

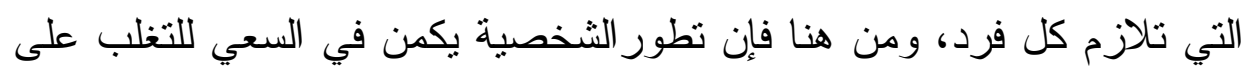

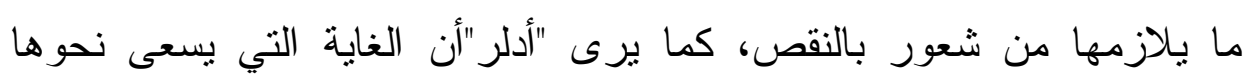

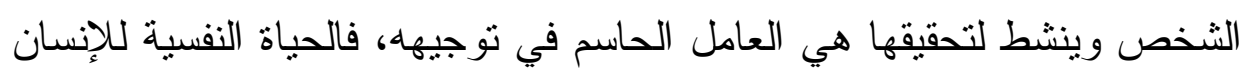

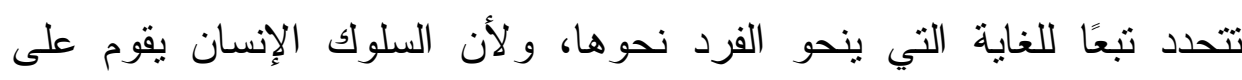
النزوع نحو الهدف، فلكي نفسر سلوك الإنسان، لابد من معرفة الهدف النهائ النهائي

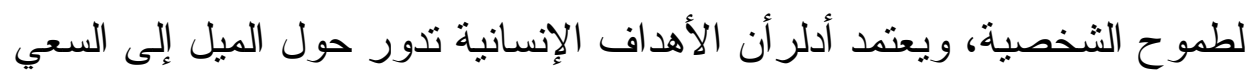

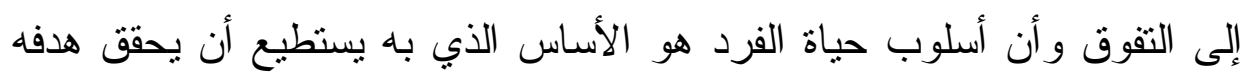

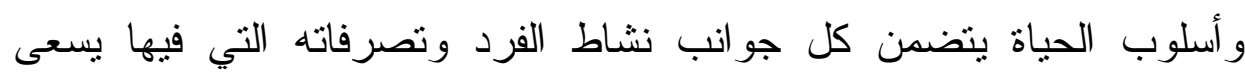
لتحقيق هدفه بخطه خاصة مميزة.

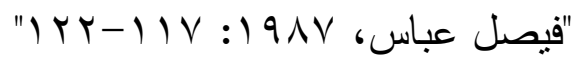

قياس مستوى الطموح: تثير "كامليا" إلى أن هناك طريقتين لقياس مستوى الطموح و هي: ا ـ قياس مستوى الطموح عن طريق إجر اء بعض التجارب المعملية التـي يقوم فيها الثخص المر اد قياس مستوى طموحه بأداء عمل معين. 


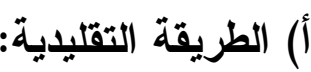

ب) مقياس الاختلاف التحصيلي:

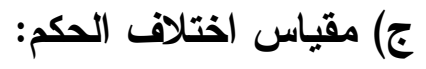

د) مقياس الاختلاف "الذاتي":

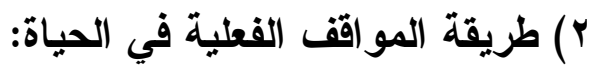

لقد انتقل قياس مستوى الطموح من التجارب المعطلية إلـى قياســهـ عـن طريق المواقف الحياتية كما فعل "تثايلد وزملائه عهو ا" فقد حاولوا الربط بين شو اهد الحياة اليومية وبين التجارب المعملية.

كما وقد قام بعض الباحثين بتصميم مقاييس لمستوى الطموح منهم "وورل

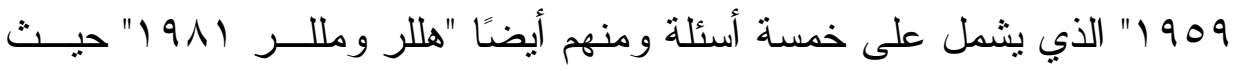

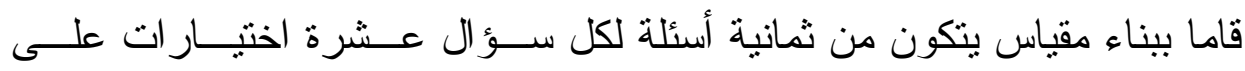

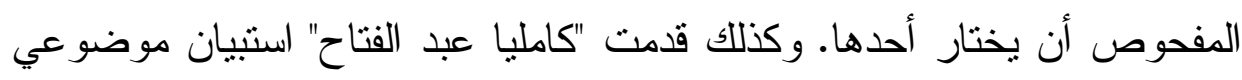

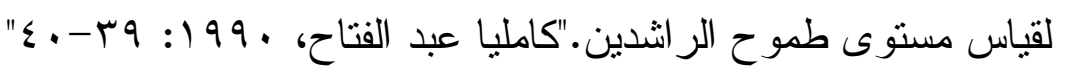

ويذكر "ممدوح الكناني،أحمد الكندي" أن مستوى الطموح يقاس من خلال

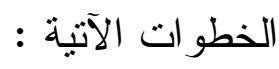

- - تحديد الاداء الاسبق للفرد في مهمه معينة. - تحديد مايطمح أو مايتوقعة الفرد من أداء في المحاولة التالية لأدائة. - - تحديد الأداء الفعلي للفرد في المحاولة التالية. 
ويسمى الفرق بين مستوى الأداء الأول ومستوى الأداء المتوقع الثاني أو

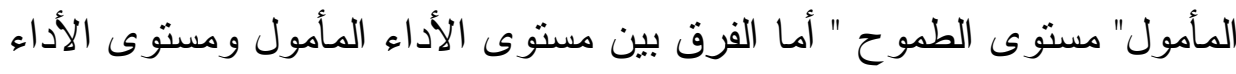

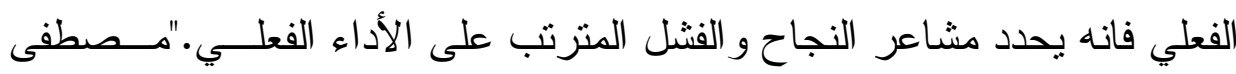

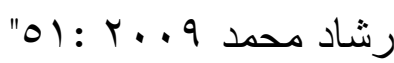

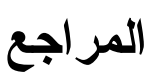

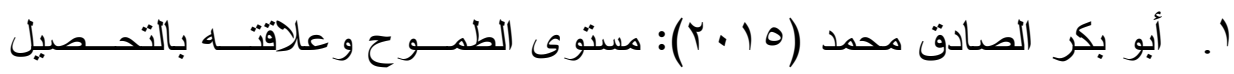

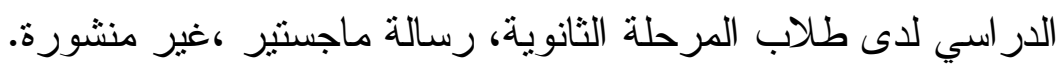
r. إبر اهيم جيد (1911):) علاقة مستوى الطموح بالتفوق الدراسـي، رســالة ماجستير • جامعة عين شمس.

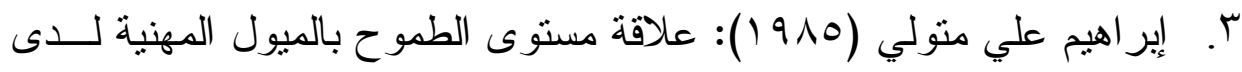
طلاب وطالبات الثانوية العامة، رسالة ماجستير • جامعة الزقازيق.

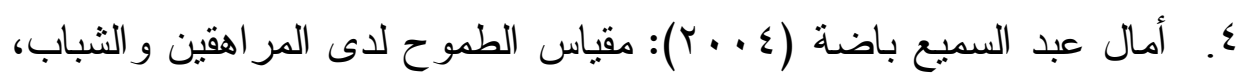
القاهرة ، مكتبة الانجلو المصرية.

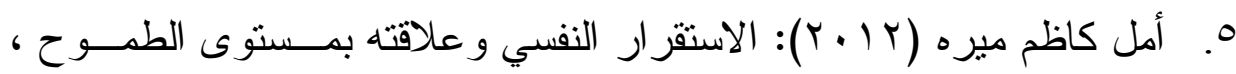

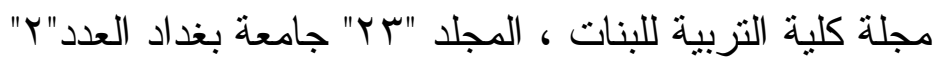
T. السيد محمد محمد فرحات (ץ 919): در اسة العلاقة بين مسنوى الطهـوح و التو افق الثخصي و الاجتماعي لدى طلاب المرحلة الثانوية العامة، رسالة

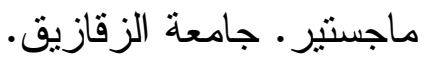


V. توفيق محمد توفيق (0 . . r): مستوى الطموح و علاقته ببعض المتغيــرات في ضوء الثقافة السائدة لدى طلبة الجامعــة الاســلامية بغــزة ، رســالة ماجستير •

^. حمدي زيدان (ع ا • ب): الطاقة النفسية وقوة الذات، الطبعـــة الأولـىى، دار الكتاب الجامعي. دولة الإمار ات العربية المتحدة.

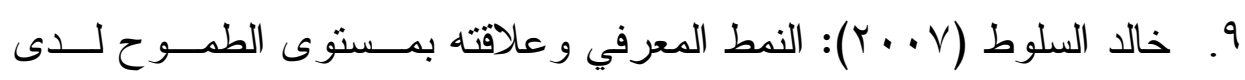
طلاب كلية التربية في جامعة اليرموك في ضوء بعض المتغير ات، رســالة ماجستير غير منشورة، الأردن.

• 1. رشاد عبد الفتاح محمد (11 (Y): در اسة مستوى الطموح و علاقته بتقـدير

الذات لدى المر اهقين مكفوفي البصر ، رسالة دكتور اه. جامعة عين شمس.

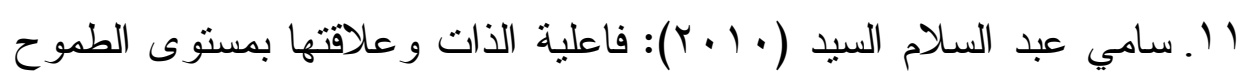
المهني، رسالة ماجستير • جامعة بنها.

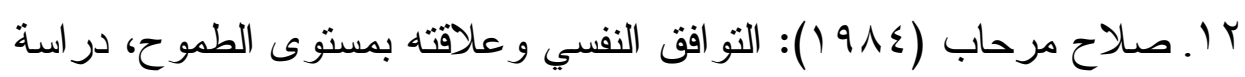

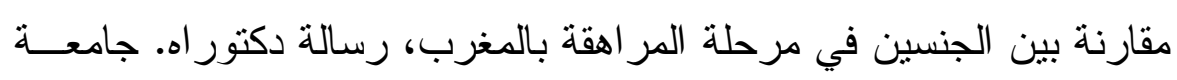
عين شمس.

13.Better, E. (1998) Relation of Locus of control to Aspiration level and to competive Anxiety psychological Reports.

14.Al. et Al (1985) Self concept and evl of Aspiration in igh and owashieringighersecondreyupilspsychogical researches al, 8, 0.2 pp49-53. 
15.Al. et. al (1985) sslFconcept and rel of Aspiration in igh and OwaShievingigher secondary upils" Psychogical Researches al, 8 0.2 pp49-53.

16.Strand and Winston (2008): Level of educational aspirations and factors affecting the level of ambition among secondary school students. 